\title{
Review \\ Roles of Oxytocin in Stress Responses, Allostasis and Resilience
}

\author{
Yuki Takayanagi $*$ (D) and Tatsushi Onaka \\ Division of Brain and Neurophysiology, Department of Physiology, Jichi Medical University, \\ Tochigi 329-0498, Japan; tonaka@jichi.ac.jp \\ * Correspondence: t-yuki@jichi.ac.jp
}

check for updates

Citation: Takayanagi, Y.; Onaka, T. Roles of Oxytocin in Stress

Responses, Allostasis and Resilience. Int. J. Mol. Sci. 2022, 23, 150. https:// doi.org/10.3390/ijms23010150

Academic Editors:

Kazunori Kageyama

and Takahiro Nemoto

Received: 19 November 2021

Accepted: 19 December 2021

Published: 23 December 2021

Publisher's Note: MDPI stays neutral with regard to jurisdictional claims in published maps and institutional affiliations.

Copyright: (c) 2021 by the authors. Licensee MDPI, Basel, Switzerland. This article is an open access article distributed under the terms and conditions of the Creative Commons Attribution (CC BY) license (https:/ / creativecommons.org/licenses/by/ $4.0 /)$.

\begin{abstract}
Oxytocin has been revealed to work for anxiety suppression and anti-stress as well as for psychosocial behavior and reproductive functions. Oxytocin neurons are activated by various stressful stimuli. The oxytocin receptor is widely distributed within the brain, and oxytocin that is released or diffused affects behavioral and neuroendocrine stress responses. On the other hand, there has been an increasing number of reports on the role of oxytocin in allostasis and resilience. It has been shown that oxytocin maintains homeostasis, shifts the set point for adaptation to a changing environment (allostasis) and contributes to recovery from the shifted set point by inducing active coping responses to stressful stimuli (resilience). Recent studies have suggested that oxytocin is also involved in stress-related disorders, and it has been shown in clinical trials that oxytocin provides therapeutic benefits for patients diagnosed with stress-related disorders. This review includes the latest information on the role of oxytocin in stress responses and adaptation.
\end{abstract}

Keywords: oxytocin; stress; hypothalamus; allostasis; resilience

\section{Introduction}

Oxytocin is primarily synthesized in magnocellular and parvocellular neurons of the paraventricular nucleus (PVN) and supraoptic nucleus (SON) of the hypothalamus. Magnocellular oxytocin neurons in the hypothalamus project to the neurohypophysis and have axon collaterals to the forebrain. Oxytocin is released from the axonal terminals in the neurohypophysis to the circulatory system, playing a pivotal role in the regulation of parturition and lactation in mammals. It is also known that parvocellular oxytocin neurons project to various brain regions and release oxytocin in the projection regions. Oxytocin is released not only from axon terminals but also from cell bodies/dendrites and possibly from axonal varicosities of magnocellular oxytocin neurons and is diffused to distal action sites. Oxytocin acts on the oxytocin receptor in various brain regions. Oxytocin neurons are activated by various stressful stimuli and release oxytocin, which modulates stress responses.

Stress is a state of threatened homeostasis in response to experiences that cause physical, emotional and psychological challenges that exceed the capacity of the individual to cope. Homeostasis is defined as maintenance of an internal environment that includes physiological variables such as heart rate, blood pressure, body temperature and blood sugar within a certain narrow range [1]. Homeostasis requires monitoring of these physiological parameters that are vital for life in order to keep values constant via feedback mechanisms. Owing to homeostasis, bodily systems are protected from being out of order due to harmful events [2]. However, various physiological parameters in fact show fluctuations depending on environmental challenges, and the concept of allostasis has recently become more prevalent. Allostasis was defined by Sterling and Eyer as "achieving stability through changes" [3]. Allostasis now refers to the regulation of internal milieu through gradual changes toward new set points. It is also thought that changes of set points by allostasis lead to other physiological and behavioral systems being driven to adapt to a changing environment. Bodily systems show adaptive processes in preparation for anticipated future changes in internal or external conditions. Shifts of set points dependent 
on conditions and activations of emergency systems are adaptive for a short period, while shifts and activations for a long period often cause overloads in various bodily systems, resulting in lifestyle-related disorders (Figure 1) [4,5]. It is important to restore the set points to their original place and to recover normal status before organs receive irreversible damage. Resilience refers to an individual's capacity to make a successful recovery from psychological or physical difficulties. These difficulties include family problems, interpersonal relationships, health problems, workplace load and financial stressors. Resilience helps a person bounce back and recover from these difficult experiences [6]. In other words, resilience is the ability to restore a shifted set point and emergency system to their original setting after coping with difficulties and regain homeostasis (Figure 1). Molecular and neural mechanisms underlying allostasis and resilience still remain to be clarified. The present review focuses on the role of oxytocin in the control of stress responses, allostasis and resilience.

A

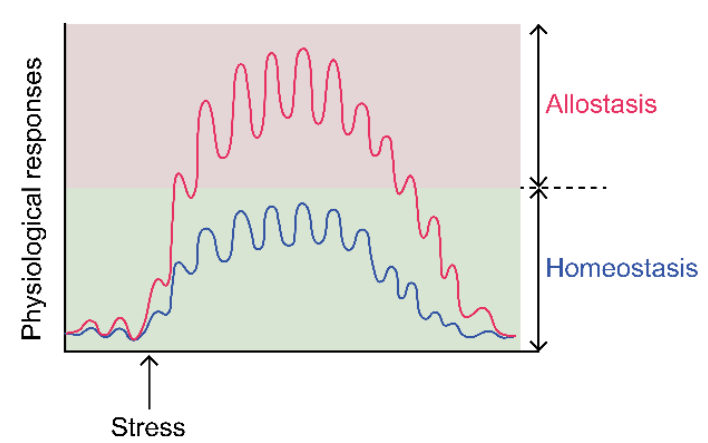

B Allostatic load/overload

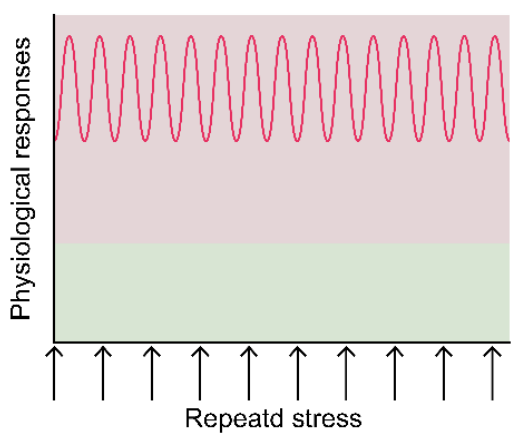

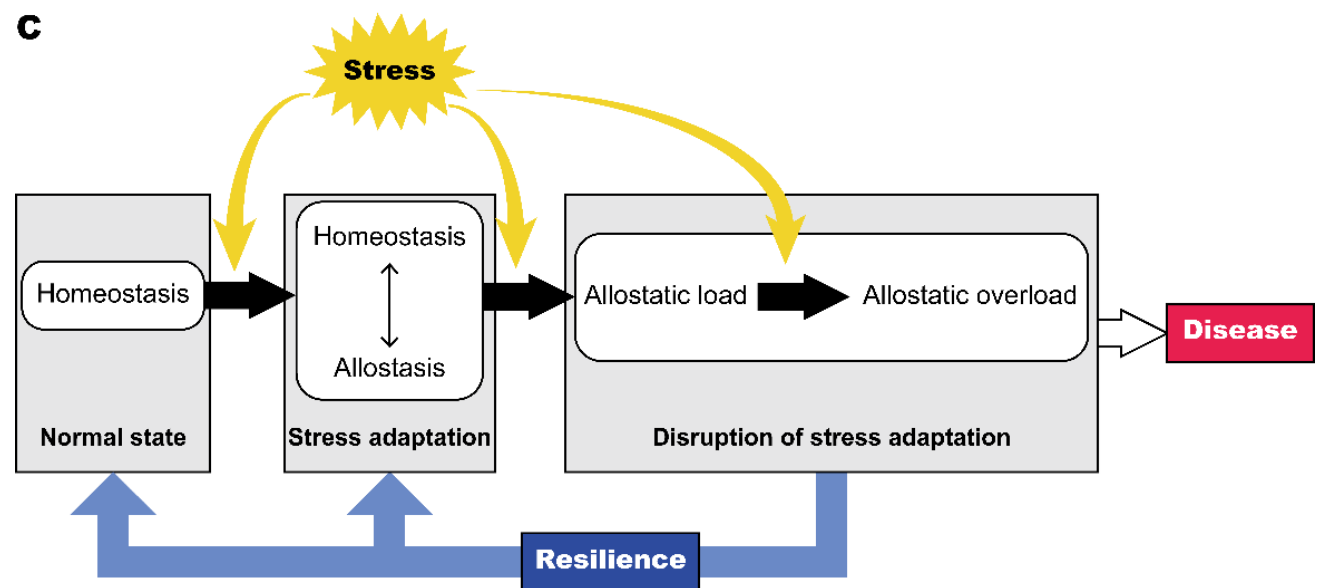

Figure 1. Allostasis and resilience. (A) Physiological responses to stressful stimuli in bodily systems including the autonomic nervous system, hormone responses, and inflammatory cytokines. Homeostasis refers to the body's ability to maintain a stable internal milieu. Allostasis refers to the process that maintains homeostasis and to the drive of other physiological and behavioral systems by changing set points depending on changing environments. A normal allostatic response lasts for an appropriate time after stress, then returns to a normal level and ends [7]. (B) Allostatic load/overload is a state of chronically sustained allostasis that is induced by chronic stressful stimuli or inefficient management of allostasis. Allostatic load is also provoked by repeated normal responses over time, lack of adaptation, prolonged responses due to delayed shutdown and inadequate responses [7]. (C) Allostatic load or overload persistently activates physiological responses (neuroendocrine, cardiovascular and emotional responses) and accelerates the progression of various diseases. Resilience acts to restore physical and psychological conditions from a failed state of allostasis to a normal state. 


\section{Stress Responses and Oxytocin}

\subsection{Activation of Oxytocin Neurons and Facilitation of Oxytocin Release after Various} Stressful Stimuli

Animal studies have shown that various physiological and psychological stressful stimuli, such as noxious stimuli [8], conditioned fear stimuli [9], social defeat stress [10-14], immobilization stress [15], shaker stress [16], forced swimming [17,18], cold stress [19], highintensity exercise [20] and immune challenges by lipopolysaccharides [21] or interleukin1 [22], activate oxytocin neurons and facilitate the release of oxytocin into the plasma and within the brains of mice and rats [23-25]. Social instability stress in adolescent female rats has been reported to decrease oxytocin immunoreactivity in the hypothalamic paraventricular nucleus [26] possibly due to oxytocin release. Synchronic oxytocin release into the plasma and within the brain has been shown during forced swimming stress [18] and shaker stress [16]. On the other hand, dissociated oxytocin release has also been reported during social defeat stress [13] in rats.

In humans, oxytocin release after stressful stimuli has also been reported. Physical running [27-30], psychological stress such as uncontrollable noise in women [31] and a Trier social stress test that consists of a public speaking task and mental arithmetic performed in front of an audience $[27,32,33]$ have been shown to increase plasma or salivary oxytocin concentrations. A positive correlation between plasma oxytocin concentrations and anxiety or relational distress has been shown in healthy humans [34-36] and in patients with a social anxiety disorder [37]. High levels of plasma oxytocin have also been reported in subjects with high depressive scores [38]. The number of oxytocin neurons [39], expression of oxytocin mRNA in the hypothalamus [40] and plasma oxytocin concentrations [41] have also been shown to be increased in depressed subjects.

However, apparently discrepant data concerning plasma oxytocin concentrations in stressed conditions have also been reported. Exercise of short duration and high intensity has been shown not to significantly change plasma oxytocin concentrations in humans [42,43]. In rats, plasma oxytocin levels have been reported not to change after exercise [44]. Plasma or urine oxytocin concentrations have also been reported to not be significantly changed by a Trier social stress test in children [45] and in women [46,47] and by a speech stress task in women [48]. Furthermore, decreased oxytocin levels have been observed in the cerebrospinal fluid (CSF) of women with a history of child abuse [49], in the CSF of suicide attempters [50], and in the plasma of patients with post-traumatic stress disorder (PTSD) [51]. Decreased oxytocin concentrations in the blood have been found in patients with depression [52,53]. Research concerning postpartum depression has shown that plasma oxytocin levels were inversely related to depressive symptoms [54]. These differences in data might be caused by differences in subjects, species, stressful stimuli applied and experimental conditions. The interpretation of oxytocin levels in psychiatric diseases is complex. A decrease in oxytocin levels in patients with psychiatric diseases might be a cause of the development of anxiety or depression-like symptoms in these patients, and might not be a result of stressful stimuli. Considering these discrepant findings, oxytocin does not appear to be a general biomarker for psychiatric disorders.

\subsection{Roles of Oxytocin in Stress Responses}

Oxytocin regulates stress responses in the neuroendocrine system, autonomic nervous system, immune system and behaviors. In many studies using both animal and human subjects, oxytocin has been shown to reduce the activity of the hypothalamic-pituitary-adrenal (HPA) axis [55-60], regulate autonomic stress responses [19,61-64], attenuate inflammation [65-67] and reduce anxiety-related behaviors [23,24,68-70]. Oxytocin-deficient female mice, but not oxytocin-deficient male mice, have been reported to show increased anxietyrelated behaviors in an elevated plus maze test [71]. A high plasma level of corticosterone after shaker stress and novel environmental stress-induced hyperthermia have been also observed in oxytocin-deficient female mice [71]. These results suggest that endogenous oxytocin reduces the activity of the HPA axis and the anxiety-related behavioral system during 
stress. In many studies in which the effects of oxytocin administration on anxiety-related behavior and fear conditioning were assessed, oxytocin was shown to decrease anxietyrelated behavior $[68,70,72]$, attenuate contextual fear expression and facilitate extinction in rodents [68,70].

Studies with human subjects have also shown anxiolytic effects of intranasally administered oxytocin [70]. Oxytocin administration and social support have been shown to decrease cortisol levels and reduce anxiety during a Trier social stress test in healthy men [73]. Intranasal oxytocin has been reported to reduce the activity of the amygdala region in response to fearful faces or fear scenes in healthy subjects [74-79]. In patients with generalized social anxiety disorder, hyper-reactivity to fearful faces in the left amygdala has been reported to be attenuated by intranasal oxytocin [80].

The regulation of stress responses by oxytocin is observed in a variety of social situations. Social relationships are important for maintaining both mental and physical health $[81,82]$. Social buffering, the attenuation of stress responses in affiliative social conditions, is partly responsible for the positive impact of social relationships. The oxytocin system has been shown to attenuate stress responses in the presence of socially affiliative conspecifics [83]. In female prairie voles, cohabitation with a male partner has been shown to reduce anxiety-related behavior and corticosterone levels in response to immobilization stress via the hypothalamic oxytocin system [84]. In humans, social buffering is associated with a single nucleotide polymorphism of the oxytocin receptor gene [85]. Some species have been shown to exhibit consolation-like behavior, which attenuates stress responses, toward distressed affiliative conspecifics. Oxytocin has also been implicated in consolationlike behavior. Prairie voles have been reported to show consolation-like allogrooming behavior towards distressed partners via the oxytocin system. Allogrooming decreases anxiety-related behaviors and corticosterone levels [86]. Mandarin voles [87] and female mice [88] have also been reported to show consolation-like allogrooming behavior towards socially defeated partners via the oxytocin system.

Parent-infant interaction in humans, which is positively correlated with oxytocin levels in both parents and infants, has been reported to decrease salivary cortisol levels [89]. Mating, which activates the oxytocin system, has been shown to decrease anxiety-related behaviors in male rats [90]. The oxytocin receptor expressed in melanin-concentrating hormone $(\mathrm{MCH})$ neurons of the lateral hypothalamus has been shown to be involved in mating-induced decreases in depressive-like behavior in male mice [91]. It is known that wound healing is impaired by psychological stress in rodents and humans. Oxytocin administration has been shown to decrease cortisol and facilitate wound healing in socially isolated hamsters, while an oxytocin receptor antagonist has been reported to delay wound healing in socially housed hamsters [92].

These findings suggest that the oxytocin system is activated in response to stress and in socially affiliative conditions, and that the oxytocin system attenuates the stress response. The oxytocin system also indirectly alleviates the stress response in distressed individuals by inducing the seeking of social support and by receipt of social support [45,73,85,93-95].

On the other hand, anxiogenic action of oxytocin has also been reported. Chronic injection of oxytocin has been shown to increase anxiety-related behavior in male mice [96] but not in female rats with high anxiety [97] or in lactating female rats [98]. Viral vectorinduced overexpression of the oxytocin receptor in the lateral septum has been shown to enhance contextual fear in socially defeated mice [99]. Interestingly, chronic oxytocin administration has been reported to enhance anxiety-related behaviors in male rats via inducing alternative splicing of the hypothalamic corticotropin-releasing factor receptor $2 \alpha(\operatorname{Crfr} 2 \alpha)$ and shifting the splicing ratio from the anxiolytic membrane-bound CRFR $2 \alpha$ form to the soluble CRFR2 $\alpha$ form [100]. In healthy subjects, oxytocin has been shown to facilitate recognition of threatening stimuli and fearful facial expressions [101-103], suggesting that oxytocin seems to enhance anxiety. No significant effects of intranasal oxytocin on core symptoms in patients with social anxiety disorder and depression have also been reported [104]. The effects of oxytocin appear to vary considerably depending on 
the gender, social context, and mode of oxytocin administration; treatment via oxytocin administration will therefore require further in-depth research. Oxytocin also has been shown to be involved in early life stress and brain plasticity (see another review [105]).

\subsection{Site of Action of Oxytocin with Respect to Stress Responses}

The oxytocin receptor is distributed widely within the brain, which regulates stress responses, including the prefrontal cortex, limbic area, hypothalamus, raphe and medulla oblongata [106].

\subsubsection{Prefrontal Cortex}

The oxytocin receptor in the prelimbic or infralimbic prefrontal cortex and in the anterior cingulate cortex (ACC) has been shown to have anxiolytic effects.

Oxytocin injection (male rats) [107] and activation of oxytocin receptor-expressing neurons (male mice but not female mice) [108] in the prelimbic prefrontal cortex have been shown to decrease anxiety-related behavior. Optogenetic activation of the prelimbic prefrontal cortex oxytocin terminals projecting from the PVN oxytocin neurons has been shown to reverse paternal deprivation-induced increases in anxiety-related behavior and social avoidance in mandarin voles [109]. In the infralimbic prefrontal cortex, oxytocin has been reported to induce fear extinction [110]. Furthermore, social interaction-induced effects on contextual fear memory extinction have been shown to be mediated by infralimbic oxytocin signaling [111].

Chronic social defeat stress has been reported to decrease expression of oxytocin receptor mRNA in the ACC, inducing anxiety-related behaviors. Oxytocin injection into the ACC has been shown to attenuate nociceptive responses and anxiety-related behavior in animals with neuropathic pain by selectively blocking the maintenance of presynaptic longterm potentiation (LTP) but not postsynaptic LTP [112]. In humans, intranasal oxytocin has been shown to reduce activation of the dorsal part of the ACC in response to fearful faces in men, while intranasal oxytocin increased ACC activation in women [113].

\subsubsection{Bed Nucleus of the Stria Terminalis}

The oxytocin system in the bed nucleus of the stria terminalis (BNST) has been reported to have anxiogenic effects.

Fear conditioning has also been shown to activate oxytocin neurons in the PVN and SON, and to induce oxytocin release in the dorsolateral BNST [114]. Oxytocin signaling in the dorsolateral BNST has been shown to facilitate acquisition of cued fear in fearpotentiated startle [115]. Inhibition of the oxytocin receptor in the anteromedial BNST has been reported to restore normative social approach behavior following social defeat in California mice [10]. Oxytocin neurons in the medioventral BNST, from which fibers extend into the anteromedial BNST, anterior hypothalamus and lateral hypothalamus, act on the induction of social stress-induced social anxiety behaviors including social vigilance and avoidance in California mice [116].

\subsubsection{Hypothalamus}

The oxytocin receptor in the PVN has been reported to have anxiolytic effects and the oxytocin receptor in the lateral hypothalamus has been shown to modulate depressivelike behavior.

Local injection of oxytocin into the PVN of male rats [117] and female prairie voles [118] has been shown to decrease anxiety-related behavior. Oxytocin has been reported to increase the activity of GABAergic neurons in the PVN, and blockade of the $\mathrm{GABA}_{\mathrm{A}}$ receptor in the PVN has been shown to eliminate the oxytocin-induced decreases in anxiety-related behavior and corticosterone levels following stress in female prairie voles [118]. Oxytocin has also been reported to decrease the activity of corticotrophin-releasing hormone $(\mathrm{CRH})$ neurons in the PVN following stress in voles [118]. The oxytocin receptor is expressed in CRH neurons of the PVN, and oxytocin released by acute salt loading has been suggested to tonically inhibit PVN CRH neurons via the oxytocin receptor [119]. 
The oxytocin receptor expressed in $\mathrm{MCH}$ neurons in the lateral hypothalamus has also been shown to attenuate depressive-like behavior in sexually naïve females, but to augment depressive-like behavior in late postpartum female mice [91].

\subsubsection{Lateral Septum}

The oxytocin receptor in the lateral septum has been reported to have both anxiogenic and anxiolytic effects. Apparently, the contradictory findings in these reports remain to be explained.

Oxytocin application has been reported to increase recall of negative events and stressful stimuli [102,120]. Deletion of the oxytocin receptor or injections of oxytocin antagonists in the lateral septum of male mice have been reported to decrease freezing behavior in social defeat stress-induced contextual fear and to block social aversion toward aggressive resident mice. Conversely, overexpression of the oxytocin receptor in the lateral septum has been reported to exacerbate freezing behavior in social defeat stress-induced contextual fear and social defeat stress-induced social aversion [99]. These results suggest that oxytocin in the lateral septum potentiates fear by facilitation of social fear memory. Activation of oxytocin receptor-expressing neurons in the lateral septum projecting to the horizontal diagonal band of Broca has been shown to induce anxiety-related but not depressive-like behaviors via GABA in mice, suggesting anxiogenic action of the oxytocin receptor in the lateral septum [121].

On the other hand, there have been studies showing that oxytocin in the lateral septum has anxiolytic effects. Oxytocin injection into the lateral septum of male mice has been reported to abolish social fear expression in a social-fear-conditioning paradigm [122]. In addition, the naturally activated oxytocin system in lactating mice has been reported to prevent social fear expression in a social-fear-conditioning paradigm, while silencing of oxytocin neurons in the PVN projecting to the lateral septum has been shown to enhance social fear in lactating female mice [123].

\subsubsection{Amygdala}

The oxytocin receptor in the central amygdala $(\mathrm{CeA})$ has been shown to have anxiolytic action in various studies. However, contradictory data have also been reported. Oxytocin in the amygdala has also been reported to facilitate the recognition of emotions, leading to modulation of stress-coping behavior.

Oxytocin is known to reduce fear and anxiety by reducing the activity of the amygdala. Oxytocin injection into the CeA has been shown to attenuate long-term isolation-induced depressive-like and anxiety-related behaviors in male mice [124] and to decrease anxietyrelated behavior in female rats [125]. Activation of the CeA terminals from oxytocin neurons in the hypothalamus has been shown to decrease contextual freezing in fear-conditioned female rats [126]. Injection of an oxytocin agonist into the CeA has been reported to decrease freezing behavior in fear conditioning test. This phenomenon has been reported to be mediated by activation of oxytocin receptor-expressing GABAergic neurons in the lateral part of the CeA that inhibit neurons in the medial part of the CeA projecting to the periaqueductal gray [127]. However, mixed and contradictory data concerning the effects of oxytocin on fear conditioning in the basolateral amygdala and the CeA have also been reported (Please see other reviews for details [24,69]).

Oxytocin in the amygdala may switch stress-coping behavior. Injection of an oxytocin receptor antagonist into the $\mathrm{CeA}$ of rat dams has been reported to prevent the switch from self-defense freezing behavior to offspring protective behavior in mothers in response to exposure to a threatening situation, and pups have been shown not to acquire fear learning from these mothers whose amygdala oxytocin receptor was blocked [128].

Oxytocin in the amygdala also may modulate stress coping behavior by facilitating recognition of emotion. Oxytocinergic projections from the PVN to the CeA are necessary for discrimination of both positive and negative emotions of unfamiliar conspecifics in male and female mice [129]. 


\subsubsection{Raphe Nucleus}

The oxytocin receptor in the raphe nucleus has been shown to have anxiolytic actions. The oxytocin receptor is expressed in approximately half of the serotoninergic neurons in the raphe nucleus, and local injection of oxytocin into the median raphe decreases anxietyrelated behaviors by facilitation of serotonin release, possibly via the serotonin $2 \mathrm{~A} / 2 \mathrm{C}$ receptor [72]. However, deficiency of the oxytocin receptor in serotoninergic neurons in the raphe nucleus has been shown to have no significant influence on anxiety-related behavior, but to enhance aggression only in male mice [130]. The discrepancy in results may be caused by the difference in experimental procedures. The former study showed that oxytocin-induced anxiolytic actions were blocked by a serotonin receptor antagonist. The latter study showed that mice deficient in the oxytocin receptor in serotonin transporterexpressing cells had no obvious changes in anxiety-related behavior. Lifelong deficiency in the oxytocin receptor might have induced compensatory mechanisms and, as a result, the knockout mice might have shown no obvious phenotypes.

\subsubsection{Medulla Oblongata}

The oxytocin receptor in the dorsal motor nucleus of the vagus has been shown to reduce visceral stress responses. Activation of oxytocin neurons in the PVN projecting to the dorsal motor nucleus of the vagus has been reported to prevent the delayed gastric emptying observed following acute or chronic heterotypic stress and to increase gastric tone and motility following chronic heterotypic stress in rats [131].

\section{Allostasis and Oxytocin}

Concerning the effects of oxytocin on adaptations to stress, it has recently been pointed out that oxytocin plays a pivotal role not only in maintaining homeostasis, but also in allostasis. The concept of allostasis was proposed about 30 years ago. Allostasis is efficient adjustment by organisms to various conditions achieved by altering the set point of bodily parameters and controlling them predictively. The regulatory scheme for correcting errors through feedback mechanisms to maintain a stability is homeostasis. Regulation of changes in the set point and efficient prevention of errors by prediction and feedforward mechanisms, in combination with switching the coping strategy depending on the environment, is referred to as allostasis. Both regulation systems are important for complementary maintenance of body internal milieu. The brain plays an essential role in the prediction of future demand and in a change to an appropriate coping strategy for maintaining the bodily system [132].

\subsection{Oxytocin in the Concept of Allostasis}

Oxytocin has been shown not only to facilitate prosocial or socially positive behavior, but also apparently anti-social or socially negative behaviors, including aggression, depending on the situation [133]. Oxytocin has been shown to facilitate in-group trust, cooperation and conformity, but also aggression toward competing out-groups [134-136]. The results of those studies show that oxytocin facilitates not only pro-social behavior, but also anti-social behavior, depending on the social environment. Oxytocin decreases meal size and induces satiety in adult animals, while oxytocin induces the onset of feeding behavior at birth and maintains food intake during the postnatal period [137]. Induction of satiety by oxytocin may contribute to food sharing in group life and may be adaptive. On the other hand, initiation of food intake by oxytocin at birth is essential for survival. Thus, it is possible that the apparently opposite effects of oxytocin on food intake dependent on developmental states are both adaptive. It is likely that effects of oxytocin depend on the context and that oxytocin acts as an allostatic hormone to facilitate adaptation, integration and stability in changing environments [138]. The oxytocin system might facilitate the sensing of internal or external signaling [139] and contribute to the adjustment of set points, depending on conditions. For example, regarding the perception of social signals, oxytocin has been shown to increase the signal-to-noise ratio in olfactory signaling via 
exciting inhibitory neurons [140] and in auditory signaling via balancing inhibition with excitation [141]. Thus, it seems that oxytocin increases the salience of social stimuli, induces plasticity and facilitates recognition of the environmental context in order to adapt to changing environments. The oxytocin system also facilitates learning of stimulus-outcome associations and assists in future predictions to adapt bodily systems according to changing environments [138]. Oxytocin activity has been reported to weaken the decline of the subjective value of delayed reward and to resist immediate temptation impulses, leading to future-oriented behavior [142]. Oxytocin also facilitates reversal learning to increase behavioral flexibility in humans [142] and in Brown Norway rats [143]. These actions have been shown to be impaired in oxytocin receptor-deficient mice [144], suggesting that the oxytocin system is essential for the ability to learn a new strategy for behavioral flexibility and the ability to adapt to a changing environment. In humans, oxytocin administration has also been reported to increase learning performance during conditioning in fear conditioning tests, inducing rapid adaptations to frightening stimuli and augmenting fear responses in aversive contexts [145]. These results have led to the argument that oxytocin is not simply anxiolytic but induces rapid and flexible adaptation to aversive situations. Under stressful conditions, oxytocin reduces passive freezing behavior [146], increases stress-induced analgesia [147,148], and increases stress-induced oxygen consumption [23] to facilitate muscle movement for active coping behaviors.

The oxytocin system has been shown to play a role in allostasis during reproductive behavior. Oxytocin is released at the time of delivery and plays not only a pivotal role in uterine contraction in mothers, but also in analgesia in the newborns [149]. Oxytocin has been shown to increase the threshold of pain sensation in newborn rats (P0) via reduction of the depolarizing action of GABA on nociceptive neurons [150]. Oxytocin reduces intracellular chloride concentration and switches GABA function from excitation to inhibition [151]. Maternal oxytocin during delivery might also exert a neuroprotective action on fetal neurons during parturition. The shift in GABAergic actions induced by oxytocin also changes the balance of excitation and inhibition in neural circuits and constitutes an important element of allostatic systems.

Oxytocin is also involved in allostasis during lactation. In lactating rodents, suckling stimuli from pups facilitate oxytocin release within the brain and raise the set point for the induction of anxiety in response to extrinsic factors. Oxytocin induces not only an anxiolytic action, but also evokes active coping behaviors such as maternal aggression toward intruders [152] and protective behavior to threatened signals [128] in order to defend their pups.

\subsection{Adaptation to Changing Environments in the Oxytocin System}

The oxytocin system shows adaptive changes dependent on internal and external conditions. The activity of oxytocin systems can be plastically changed via the modulation of the intrinsic properties of oxytocin neurons themselves, and via modulation of input signals to oxytocin neurons, leading to modulation of physiological set points to adapt to changing environments. The oxytocin receptor also shows plastic changes during adaptation.

For example, during pregnancy, the activity of oxytocin neurons has been shown to be suppressed. Oxytocin neurons receive long-term inhibitory inputs due to plasma volume expansion and possible hyponatremia during pregnancy. Nitric oxide [153] and allopregnanolone [154] have been shown to inhibit the activity of oxytocin neurons. Inputs of excitatory afferents to oxytocin neurons have also been shown to receive suppressive presynaptic control during pregnancy. Noradrenergic projections from A2 noradrenergic neurons in the nucleus tractus solitarius (NTS) are presynaptically suppressed by the activation of $\mu$-opioid receptors during pregnancy. At the level of axonal terminals in the neurohypophysis, oxytocin release is suppressed by co-released dynorphin. On the other hand, synthesis of oxytocin has been shown to be maintained by relaxin and estrogen, leading to the accumulation of oxytocin so that a large amount of it is released at the appropriate time during delivery [155]. The oxytocin system also shows adaptive changes 
during lactation. Periodic release of oxytocin during lactation is induced by the synchronous and explosive bursting of oxytocin neurons in the SON and PVN. These bursts appear with long intervals (5-20 min) despite continuous suckling stimuli and are observed only during lactation [156]. This system involves dramatic plastic changes in the SON and PVN during the lactation period [156]. Sucking with skin-to-skin contact facilitates oxytocin release within the brain in both the mother and pups [157].

Oxytocin systems are associated with circadian rhythms. Circulating concentrations of oxytocin rise in the light phase and decline gradually in the dark phase in mice [158]. Oxytocin neurons are activated by food intake, and the number of activated oxytocin neurons per unit amount of food intake (that is, the sensitivity of oxytocin neuron activity in response to food intake) was higher in the light phase than at night-time [159]. The higher oxytocin signaling contributes to a smaller meal size in the inactive light phase of nocturnal mice $[63,159]$.

Oxytocin systems also show adaptive changes during chronic stress. Hypothalamic oxytocin neurons projecting to the dorsal vagal complex have been shown to be more active increased in rats during adaptation to chronic restraint stress, consistent with a view that oxytocin is involved in stress adaptations of the autonomic nervous system [160]. On the other hand, accumulating evidence shows that stressful environments in early life suppress the oxytocin system, leading to long-lasting physiological and behavioral changes [105].

Despite the growing interest in allostasis, research is still in its infancy. More work focused on the aspects of allostasis is needed for understanding detailed mechanisms underlying the allostatic effects of oxytocin.

\section{Resilience and Oxytocin}

Oxytocin has also been shown to be associated with increased "resilience" following excessive stress or adversity. Resilience is a complex concept that has been defined from the perspectives of many different research fields, but it can be summarized as the ability to maintain health and adapt positively despite adversity. Resilient persons have a decreased risk of developing cardiovascular diseases and decreased prevalence of major mental illness during their lifespan $[161,162]$. Resilience is considered to be associated with less reactivity of the HPA axis and greater parasympathetic tone, compared to the status of an individual in stressful conditions [162]. The concept of resilience is used to understand individual differences in stress responses and strategies for coping with stress. Thus, resilience is an important target for prevention of and intervention in stress-related disorders. Although it has been difficult to uncover molecular and neural circuits associated with resilience in research using human subjects, research using animal models has progressed in the past decade and the neurobiological mechanisms of resilience have become clearer.

In animal models, learned helplessness or repeated social defeat stress, which induce depressive-like behavior, has been used to distinguish between susceptible and resilient animals. Early life stress such as stress from maternal separation and reduced bedding material has also been used in animal models of adversity experienced during childhood and adolescence in humans [163]. Affiliative maternal parenting fosters resilience through its effects on the development and maturation of the brain [164]. The development of resilience requires plasticity in order for organisms to adapt to changing environments and to establish social relationships. Social relationships include social support and belonging to a social group. Oxytocin is involved in the adaptation to changing environments and in the establishment of social relationships, suggesting that oxytocin plays a key role in demonstrating and developing resilience [164].

\subsection{Roles of Oxytocin in Resilience in Animal Models}

Animal studies have shown that oxytocin has persistent effects facilitating resilience in a variety of stress models.

Affiliative tactile stimuli including maternal care and gentle stroking of rats by humans confer resilience against stress [165]. Gentle stroking activates oxytocin neurons in adult 
rats [166]. Experience of gentle stroking during adolescence enhances the activation of oxytocin neurons in adulthood $[167,168]$. Social enrichment has been reported to increase plasma oxytocin levels in female rats and to increase novelty-seeking behavior. Telomere length has been shown to be increased by social enrichment via oxytocin signaling, suggesting that oxytocin induced by social enrichment has an anti-aging effect [169]. In oxytocin receptor-deficient mice, an increase in defeat posturing during second social defeat stress by repeated social defeat stress was not observed [11], suggesting that oxytocin facilitates active coping behaviors in response to repeated stressors to confer resilience [170,171].

Oxytocin has also been shown to be involved in the effects of early life stress. Oxytocin signaling in the medial prefrontal cortex has been reported to promote stress resilience in response to exposure to predictable maternal separation, while reduction in the expression of the oxytocin receptor has been shown to induce stress susceptibility in response to exposure to unpredictable maternal separation stress [172]. Early-life adversity has been shown to influence vulnerability to drug abuse by weakening oxytocin systems [173]. Early-life adversity disturbs the maturation of oxytocin neural circuits and produces longlasting weakening of oxytocin systems $[105,173]$. Neonatal isolation has been reported to reduce partner preference in adult female prairie voles, and the social isolation-induced impairment in partner preference has been shown to be mitigated via pharmacological potentiation of oxytocin release by a melanocortin 3/4 agonist [174]. High oxytocin receptor-binding in the nucleus accumbens (NAc) has been shown to mediate resilience to the effects of daily neonatal isolation stress [174]. Early postnatal administration of an oxytocin receptor agonist has been shown to attenuate microglial inflammation and to normalize myelination, brain connectivity, and cognitive and anxiety-related behaviors in an early life stress model [175]. Oxytocin treatment in rodents has been reported to ameliorate maternal separation-induced behavioral deficits including depressive-like behaviors [176,177] and autistic-like behaviors [178] as well as deficits in social and cognitive memory [179]. Oxytocin administration has also been reported to hinder increases in alcohol drinking (alcohol vulnerability) induced by repeated social defeat during adolescence [180]. The mechanisms underlying the long-lasting effects of oxytocin administration remain unclear. However, oxytocin has been suggested to induce neural growth [181], expression of synaptic proteins [182] and neurogenesis [183]. Oxytocin has also been shown to facilitate the excitatory-to-inhibitory developmental shift of GABAergic neurons [184]. It is possible that these structural and functional effects of oxytocin are involved in its long-lasting actions [105].

Oxytocin has also been shown to be associated with drug vulnerability and alcohol dependence in adulthood. Oxytocin has been reported to reduce drug-abuse vulnerability via the oxytocin receptor in the NAc of adult animals [173]. Pair-housing with familiar mice has been shown to increase plasma oxytocin levels and to prevent social defeat-induced vulnerability to drug abuse $[185,186]$. Oxytocin injection has been reported to reduce alcohol cue-induced reinstatement response in rats [187]. Oxytocin has also been reported to block increased craving for alcohol in a rat model of alcoholism via the blocking of alcohol's effects on GABAergic transmission in the central amygdala [188].

Oxytocin has also been reported to modulate emotional memory. Reactivated memory becomes temporarily malleable and can integrate new information. Reducing emotional responses before the reactivation of traumatic memories is expected to alleviate PTSD-like symptoms. Single prolonged stress has been shown to induce the PTSD-like symptoms of increased anxiety and reduced arousal in vulnerable rats. In vulnerable rats, oxytocin injection has been shown to activate the prelimbic cortex and basolateral amygdala and to reverse manifestation of PTSD-like behavioral symptoms for a long period [189], suggesting that oxytocin induces emotional remodeling via plastic changes of neural activity.

Oxytocin has also been shown to be involved in individual differences of stress resilience. The resilience of rats in response to isolation-potentiated startle has been shown to be related to distribution patterns of the oxytocin receptor [190]. Distribution of vasopressin 
receptors and corticotropin-releasing peptide receptors has also been shown to be involved in individual differences [190].

Various animal studies on resilience or vulnerability have shown that oxytocin is important in the process of coping with adversities and recovering from them. Oxytocin also plays an important role in the process of development of resilience during the early-life period by strengthening the affiliative relationship between the mother and littermates.

\subsection{Roles of Oxytocin in Humans}

Early-life adversities such as childhood abuse have also been shown to be associated with lower plasma or CSF oxytocin levels in humans [49,191-193]. Female students with high basal oxytocin levels in their saliva were reported to show a positive affect after stress (an emotionally stressful video) and enhanced cognitive-emotional accuracy in a following emotional Stroop task, suggesting that oxytocin buffers negative emotion and facilitates resilience during stress [194]. Maternal depression leads to a higher prevalence of children externalizing and internalizing problems at 10 years after birth due to decreased oxytocin levels in the saliva of the children [195].

Resilience in children who developed chronic PTSD by exposure to war has been reported to be associated with genetic risk variation of the oxytocin receptor gene [196]. People who possess the AA or AG genotype of polymorphic variation (rs2254298) of the oxytocin receptor gene have been shown to be susceptible to the development of mental disorders [197,198], and interaction of the A risk allele of rs2254298 and childhood emotional neglect has been shown to be associated with reduced left-hippocampal volume [199]. Polymorphic variation (rs53576) of the oxytocin receptor gene has been shown to be associated with vulnerability to the effects of early-life adversity [200-202] and to also be associated with resilient coping in adulthood, depending on the impact of childhood family environments [203]. The combination of the rs53576 A allele and insecure attachment has been reported to be associated with an increased risk of PTSD in U.S. military veterans [204]. AA homozygotes of rs53576 carriers with exposure to high emotional trauma have been shown to have a smaller volume of the left hippocampus and disruption of the developmental shift of the source of social support from family in early life to friends or peers in adolescence [205]. On the other hand, the GG risk allele of rs53576 was shown to be associated with decreased oxytocin receptor methylation [199]. There are some reports showing a relationship between methylation of the oxytocin receptor gene and resilience in humans [206]. Oxytocin receptor DNA methylation has been shown to be associated with the development of resilience to conduct problems in a study of only children with preand post-natal adversity [206].

Stress resilience is important for preventing substance use in youth and adults, and the oxytocin system is one of the target areas in treatment for substance-use disorders [207,208]. The expression of oxytocin receptor mRNA and protein in the frontal cortex and striatum has been reported to be increased in humans with an alcohol-use disorder [187]. Oxytocin injection has been reported to reduce activity of the brain circuit related to alcohol cue reactivity in heavy drinkers [187]. In cocaine-dependent men with childhood trauma, oxytocin has been reported to reduce functional magnetic resonance imaging (fMRI) responses in the dorsomedial prefrontal cortex associated with cocaine-seeking behavior and anxiety during withdrawal, and in the amygdala, associated with responses to cocaine cues and craving [209].

Veterans exposed to combat-related trauma have been reported to show higher resting alpha activity in prefrontal regions in magnetoencephalography. The prefrontal cortex subserves working memory and cognitive control, which are disrupted in PTSD. Intranasal oxytocin administration has been reported to normalize alpha activity [210]. Some studies showed the effectiveness of oxytocin administration for amelioration of PTSD symptoms [211,212]. On the other hand, oxytocin administration in subjects who received early life stress has been reported to increase cortisol reactivity and to reduce activity of the limbic system during psychological stress, while oxytocin administration attenuated cortisol 
reactivity and reduced limbic deactivation in non-stressed subjects. The opposite effects of oxytocin in early life-stressed subjects and non-stressed subjects suggest that oxytocin may enhance stress responses in individuals with early life stress [213].

Research on resilience and oxytocin in humans is still limited. Research has been focused on the alleviation of symptoms and maintenance of mental health following adversity or trauma. Clarifying whether oxytocin is involved in processes that prevent deterioration due to adversity or that foster resilience is a topic for future research.

\section{Concluding Remarks}

Stressful stimuli activate oxytocin neurons and promote oxytocin release. Oxytocin modulates stress responses and facilitates adaptation to stress. The effects of oxytocin also depend on the individual situation and environmental context. Oxytocin has been shown to acutely modulate stress responses and to have organizational effects in subjects after early life stress (Figure 2). In this review, we show that oxytocin also plays a role in coping with persistent stress to facilitate allostasis. Allostasis facilitates adaptation not only by changing the internal milieu toward new set points but also by operating other physiological and behavioral systems in response to the changing environment. In fact, organisms show different physiological and behavioral responses in response to a certain stressful stimulus depending on the surrounding social environment. The oxytocin system plays a role in environment-dependent stress responses.

Oxytocin is receiving attention as a target for treatment of stress-related disorders, social disorders, and eating behaviors because oxytocin is considered to be well tolerated and safe for use in adults and children [214-216]. However, there are conflicting data on the effects of oxytocin administration. Oxytocin has a high affinity to the oxytocin receptor, but it also has some affinity to vasopressin receptor 1a. Thus, exogenous oxytocin application at a high dosage can activate both the oxytocin receptor and vasopressin receptor $1 \mathrm{a}$, which sometimes has effects opposite to those of the oxytocin receptor alone [144,217-220]. The proportions of the two receptors that are activated may vary depending on the procedures used in studies, possibly leading to controversial data. Oxytocin injected peripherally has been shown to hardly pass through the blood-brain barrier. Permeability of the blood-brain barrier might depend on the route of oxytocin application, and some studies showed that oxytocin injected intranasally can reach the brain in appropriate amounts or increase central endogenous oxytocin release [221-225], although there are debates concerning the permeability of intranasal oxytocin into the brain $[225,226]$. Thus, differences in oxytocin administration routes might result in contradictory data. Furthermore, the effects of oxytocin vary depending not only on the dose or route of administration, but also individual factors including genetic variations, gender, age, social environments, and early life experience [225]. Further research to understand the interactions of these factors that influence the effects of oxytocin will enable prediction of risk for stress-related disorders and will advance the clinical use of oxytocin. Oxytocin is cleared rapidly, and its rapid clearance decreases its therapeutic effects. A long-acting oxytocin analogue, which might reach the brain via peripheral injection, has been reported to affect social behaviors [227]. Activation of the endogenous oxytocin system is another strategy. This could be accomplished pharmacologically [228-230] or behaviorally [27-30,231-234] by, for example, spontaneous pleasurable emotional experiences such as human-dog interactions, massage, gentle touching, physical running and music therapy [235]. In addition, effective activation of the endogenous oxytocin system may strengthen the ability of the individual to adapt and facilitate resilience, leading not only to new therapeutics for or ways for preventing life style-related or early life trauma-related diseases, [236,237] but also health promotion. 


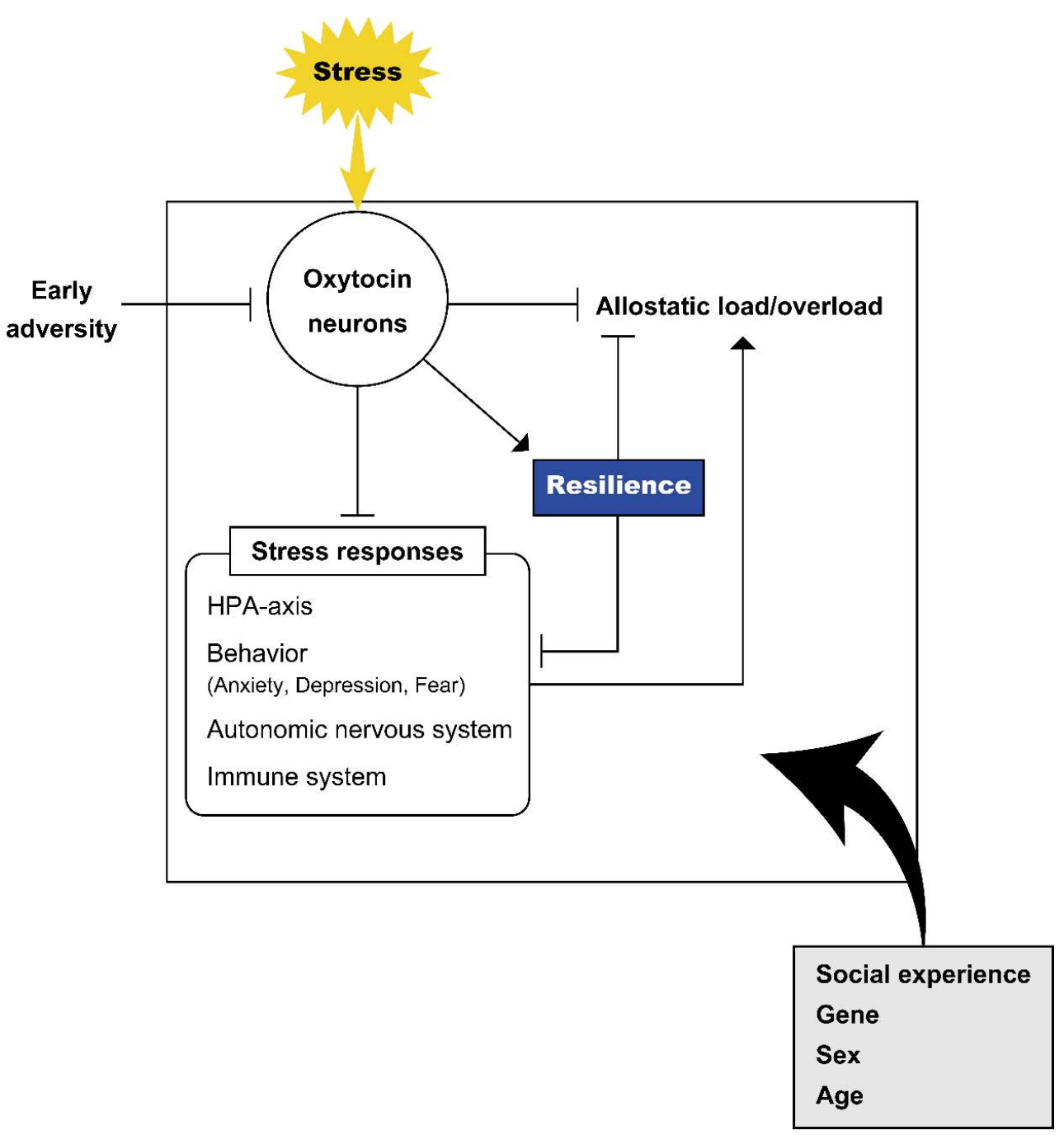

Figure 2. Oxytocin and stress. Schematic representation of the relationship of oxytocin with stress. Stress facilitates activation of oxytocin neurons and release of oxytocin. Various factors including environment and early life adversity plastically modulate activity of the endogenous oxytocin system. Oxytocin influences behavioral and neuroendocrine responses to stress (to maintain homeostasis) and plays a role in the inhibition of allostatic load/overload. Resilience facilitated by oxytocin influences the inhibition of stress responses and allostatic load/overload. Various contexts in individuals including social experience, gene, sex and age modulate the effects of oxytocin and it is possible that these contexts have impacts on the oxytocin system itself, stress responses, allostatic load/overload and resilience, leading to different outcomes.

Author Contributions: Conceptualization, Y.T. and T.O.; writing-original draft preparation, Y.T.; writing-review and editing, Y.T. and T.O.; visualization, Y.T. and T.O.; funding acquisition, Y.T. and T.O. All authors have read and agreed to the published version of the manuscript.

Funding: This research was funded by the Japan Society for the Promotion of Science, Grants-in Aid for Scientific Research from the Ministry of Education, Culture, Sports, Science, and Technology of Japan (20K07278 to Y.T., $20 \mathrm{H} 03419$ to T.O.), and by a grant for Fusion Oriented Research for disruptive Science and Technology from Japan Science and Technology Agency (JPMJFR2067to Y.T.).

Conflicts of Interest: The authors declare no conflict of interest. 


\section{References}

1. Cannon, W.B. Organization for physiological homeostasis. Physiol. Rev. 1929, 9, 399-431. [CrossRef]

2. Ramsay, D.S.; Woods, S.C. Clarifying the roles of homeostasis and allostasis in physiological regulation. Psychol. Rev. 2014, 121, 225-247. [CrossRef]

3. Sterling, P.; Eyer, J. Allostasis: A New Paradigm to Explain Arousal Pathology. In Handbook of Life Stress, Cognition and Health; Fisher, S., Reason, J., Eds.; Wiley: Chichester, UK, 1988; pp. 629-649.

4. McEwen, B.S.; Stellar, E. Stress and the individual. Mechanisms leading to disease. Arch. Intern. Med. 1993, 153, 2093-2101. [CrossRef]

5. Peters, A.; McEwen, B.S.; Friston, K. Uncertainty and stress: Why it causes diseases and how it is mastered by the brain. Prog. Neurobiol. 2017, 156, 164-188. [CrossRef]

6. Southwick, S.M.; Bonanno, G.A.; Masten, A.S.; Panter-Brick, C.; Yehuda, R. Resilience definitions, theory, and challenges: Interdisciplinary perspectives. Eur. J. Psychotraumatol. 2014, 5, 25338. [CrossRef]

7. McEwen, B.S. Protective and damaging effects of stress mediators. N. Engl. J. Med. 1998, 338, 171-179. [CrossRef]

8. Onaka, T.; Okabe, S.; Takayanagi, Y.; Yoshida, M. Noxious or Non-noxious Inputs to Oxytocin Neurons: Possible Roles in the Control of Behaviors. Interdiscip. Inf. Sci. 2015, 21, 189-195. [CrossRef]

9. Onaka, T.; Yagi, K. Differential effects of naloxone on neuroendocrine responses to fear-related emotional stress. Exp. Brain Res. 1990, 81, 53-58. [CrossRef]

10. Duque-Wilckens, N.; Steinman, M.Q.; Busnelli, M.; Chini, B.; Yokoyama, S.; Pham, M.; Laredo, S.A.; Hao, R.; Perkeybile, A.M.; Minie, V.A.; et al. Oxytocin Receptors in the Anteromedial Bed Nucleus of the Stria Terminalis Promote Stress-Induced Social Avoidance in Female California Mice. Biol. Psychiatry 2018, 83, 203-213. [CrossRef]

11. Nasanbuyan, N.; Yoshida, M.; Takayanagi, Y.; Inutsuka, A.; Nishimori, K.; Yamanaka, A.; Onaka, T. Oxytocin-Oxytocin Receptor Systems Facilitate Social Defeat Posture in Male Mice. Endocrinology 2018, 159, 763-775. [CrossRef]

12. Bosch, O.J.; Krömer, S.A.; Brunton, P.J.; Neumann, I.D. Release of oxytocin in the hypothalamic paraventricular nucleus, but not central amygdala or lateral septum in lactating residents and virgin intruders during maternal defence. Neuroscience 2004, 124, 439-448. [CrossRef]

13. Engelmann, M.; Ebner, K.; Landgraf, R.; Holsboer, F.; Wotjak, C.T. Emotional stress triggers intrahypothalamic but not peripheral release of oxytocin in male rats. J. Neuroendocrinol. 1999, 11, 867-872. [CrossRef]

14. Wotjak, C.T.; Kubota, M.; Liebsch, G.; Montkowski, A.; Holsboer, F.; Neumann, I.; Landgraf, R. Release of vasopressin within the rat paraventricular nucleus in response to emotional stress: A novel mechanism of regulating adrenocorticotropic hormone secretion? J. Neurosci. 1996, 16, 7725-7732. [CrossRef]

15. Lang, R.E.; Heil, J.W.; Ganten, D.; Hermann, K.; Unger, T.; Rascher, W. Oxytocin unlike vasopressin is a stress hormone in the rat. Neuroendocrinology 1983, 37, 314-316. [CrossRef]

16. Nishioka, T.; Anselmo-Franci, J.A.; Li, P.; Callahan, M.F.; Morris, M. Stress increases oxytocin release within the hypothalamic paraventricular nucleus. Brain Res. 1998, 781, 57-61. [CrossRef]

17. Douglas, A.J.; Johnstone, H.A.; Wigger, A.; Landgraf, R.; Russell, J.A.; Neumann, I.D. The role of endogenous opioids in neurohypophysial and hypothalamo-pituitary-adrenal axis hormone secretory responses to stress in pregnant rats. J. Endocrinol. 1998, 158, 285-293. [CrossRef]

18. Torner, L.; Plotsky, P.M.; Neumann, I.D.; de Jong, T.R. Forced swimming-induced oxytocin release into blood and brain: Effects of adrenalectomy and corticosterone treatment. Psychoneuroendocrinology 2017, 77, 165-174. [CrossRef]

19. Kasahara, Y.; Takayanagi, Y.; Kawada, T.; Itoi, K.; Nishimori, K. Impaired thermoregulatory ability of oxytocin-deficient mice during cold-exposure. Biosci. Biotechnol. Biochem. 2007, 71, 3122-3126. [CrossRef]

20. Hada, T.; Onaka, T.; Takahashi, T.; Hiraga, A.; Yagi, K. Effects of novelty stress on neuroendocrine activities and running performance in thoroughbred horses. J. Neuroendocrinol. 2003, 15, 638-648. [CrossRef]

21. Rivest, S.; Laflamme, N. Neuronal activity and neuropeptide gene transcription in the brains of immune-challenged rats. J. Neuroendocrinol. 1995, 7, 501-525. [CrossRef]

22. Ericsson, A.; Kovács, K.J.; Sawchenko, P.E. A functional anatomical analysis of central pathways subserving the effects of interleukin-1 on stress-related neuroendocrine neurons. J. Neurosci. 1994, 14, 897-913. [CrossRef]

23. Onaka, T.; Takayanagi, Y.; Yoshida, M. Roles of oxytocin neurones in the control of stress, energy metabolism, and social behaviour. J. Neuroendocrinol. 2012, 24, 587-598. [CrossRef] [PubMed]

24. Onaka, T.; Takayanagi, Y. Role of oxytocin in the control of stress and food intake. J. Neuroendocrinol. 2019, 31, e12700. [CrossRef]

25. Neumann, I.D.; Landgraf, R. Balance of brain oxytocin and vasopressin: Implications for anxiety, depression, and social behaviors. Trends Neurosci. 2012, 35, 649-659. [CrossRef]

26. Asgari, P.; McKinney, G.; Hodges, T.E.; McCormick, C.M. Social Instability Stress in Adolescence and Social Interaction in Female Rats. Neuroscience 2021, 477, 1-13. [CrossRef] [PubMed]

27. Jong, T.R.; Menon, R.; Bludau, A.; Grund, T.; Biermeier, V.; Klampfl, S.M.; Jurek, B.; Bosch, O.J.; Hellhammer, J.; Neumann, I.D Salivary oxytocin concentrations in response to running, sexual self-stimulation, breastfeeding and the TSST: The Regensburg Oxytocin Challenge (ROC) study. Psychoneuroendocrinology 2015, 62, 381-388. [CrossRef] [PubMed] 
28. Landgraf, R.; Häcker, R.; Buhl, H. Plasma vasopressin and oxytocin in response to exercise and during a day-night cycle in man. Endokrinologie 1982, 79, 281-291.

29. Hew-Butler, T.; Noakes, T.D.; Soldin, S.J.; Verbalis, J.G. Acute changes in endocrine and fluid balance markers during highintensity, steady-state, and prolonged endurance running: Unexpected increases in oxytocin and brain natriuretic peptide during exercise. Eur. J. Endocrinol. 2008, 159, 729-737. [CrossRef]

30. Hew-Butler, T.; Jordaan, E.; Stuempfle, K.J.; Speedy, D.B.; Siegel, A.J.; Noakes, T.D.; Soldin, S.J.; Verbalis, J.G. Osmotic and nonosmotic regulation of arginine vasopressin during prolonged endurance exercise. J. Clin. Endocrinol. Metab. 2008, 93, 2072-2078. [CrossRef]

31. Sanders, G.; Freilicher, J.; Lightman, S.L. Psychological stress of exposure to uncontrollable noise increases plasma oxytocin in high emotionality women. Psychoneuroendocrinology 1990, 15, 47-58. [CrossRef]

32. Pierrehumbert, B.; Torrisi, R.; Laufer, D.; Halfon, O.; Ansermet, F.; Beck Popovic, M. Oxytocin response to an experimental psychosocial challenge in adults exposed to traumatic experiences during childhood or adolescence. Neuroscience 2010, 166, 168-177. [CrossRef] [PubMed]

33. Bernhard, A.; van der Merwe, C.; Ackermann, K.; Martinelli, A.; Neumann, I.D.; Freitag, C.M. Adolescent oxytocin response to stress and its behavioral and endocrine correlates. Horm. Behav. 2018, 105, 157-165. [CrossRef] [PubMed]

34. Tabak, B.A.; McCullough, M.E.; Szeto, A.; Mendez, A.J.; McCabe, P.M. Oxytocin indexes relational distress following interpersonal harms in women. Psychoneuroendocrinology 2011, 36, 115-122. [CrossRef]

35. Taylor, S.E.; Saphire-Bernstein, S.; Seeman, T.E. Are plasma oxytocin in women and plasma vasopressin in men biomarkers of distressed pair-bond relationships? Psychol. Sci. 2010, 21, 3-7. [CrossRef] [PubMed]

36. Marazziti, D.; Dell'Osso, B.; Baroni, S.; Mungai, F.; Catena, M.; Rucci, P.; Albanese, F.; Giannaccini, G.; Betti, L.; Fabbrini, L.; et al. A relationship between oxytocin and anxiety of romantic attachment. Clin. Pract. Epidemiol. Ment. Health 2006, 2, 28. [CrossRef]

37. Hoge, E.A.; Pollack, M.H.; Kaufman, R.E.; Zak, P.J.; Simon, N.M. Oxytocin levels in social anxiety disorder. CNS Neurosci. Ther. 2008, 14, 165-170. [CrossRef]

38. Holt-Lunstad, J.; Birmingham, W.; Light, K.C. The influence of depressive symptomatology and perceived stress on plasma and salivary oxytocin before, during and after a support enhancement intervention. Psychoneuroendocrinology 2011, 36, 1249-1256. [CrossRef]

39. Purba, J.S.; Hoogendijk, W.J.; Hofman, M.A.; Swaab, D.F. Increased number of vasopressin- and oxytocin-expressing neurons in the paraventricular nucleus of the hypothalamus in depression. Arch. Gen. Psychiatry 1996, 53, 137-143. [CrossRef]

40. Meynen, G.; Unmehopa, U.A.; Hofman, M.A.; Swaab, D.F.; Hoogendijk, W.J. Hypothalamic oxytocin mRNA expression and melancholic depression. Mol. Psychiatry 2007, 12, 118-119. [CrossRef]

41. Parker, K.J.; Kenna, H.A.; Zeitzer, J.M.; Keller, J.; Blasey, C.M.; Amico, J.A.; Schatzberg, A.F. Preliminary evidence that plasma oxytocin levels are elevated in major depression. Psychiatry Res. 2010, 178, 359-362. [CrossRef] [PubMed]

42. Altemus, M.; Roca, C.; Galliven, E.; Romanos, C.; Deuster, P. Increased vasopressin and adrenocorticotropin responses to stress in the midluteal phase of the menstrual cycle. J. Clin. Endocrinol. Metab. 2001, 86, 2525-2530. [CrossRef] [PubMed]

43. Chicharro, J.L.; Hoyos, J.; Bandrés, F.; Gómez Gallego, F.; Pérez, M.; Lucía, A. Plasma oxytocin during intense exercise in professional cyclists. Horm. Res. 2001, 55, 155-159. [CrossRef] [PubMed]

44. Bakos, J.; Hlavacova, N.; Makatsori, A.; Tybitanclova, K.; Zorad, S.; Hinghofer-Szalkay, H.; Johansson, B.B.; Jezova, D. Oxytocin levels in the posterior pituitary and in the heart are modified by voluntary wheel running. Regul. Pept. 2007, 139, 96-101. [CrossRef] [PubMed]

45. Seltzer, L.J.; Ziegler, T.E.; Pollak, S.D. Social vocalizations can release oxytocin in humans. Proc. R. Soc. B. 2010, 277, 2661-2666. [CrossRef] [PubMed]

46. McQuaid, R.J.; McInnis, O.A.; Paric, A.; Al-Yawer, F.; Matheson, K.; Anisman, H. Relations between plasma oxytocin and cortisol: The stress buffering role of social support. Neurobiol. Stress 2016, 3, 52-60. [CrossRef] [PubMed]

47. Altemus, M.; Redwine, L.S.; Leong, Y.M.; Frye, C.A.; Porges, S.W.; Carter, C.S. Responses to laboratory psychosocial stress in postpartum women. Psychosom. Med. 2001, 63, 814-821. [CrossRef]

48. Cyranowski, J.M.; Hofkens, T.L.; Frank, E.; Seltman, H.; Cai, H.M.; Amico, J.A. Evidence of dysregulated peripheral oxytocin release among depressed women. Psychosom. Med. 2008, 70, 967-975. [CrossRef]

49. Heim, C.; Young, L.J.; Newport, D.J.; Mletzko, T.; Miller, A.H.; Nemeroff, C.B. Lower CSF oxytocin concentrations in women with a history of childhood abuse. Mol. Psychiatry 2009, 14, 954-958. [CrossRef] [PubMed]

50. Jokinen, J.; Chatzittofis, A.; Hellström, C.; Nordström, P.; Uvnäs-Moberg, K.; Asberg, M. Low CSF oxytocin reflects high intent in suicide attempters. Psychoneuroendocrinology 2012, 37, 482-490. [CrossRef]

51. Carmassi, C.; Marazziti, D.; Mucci, F.; Della Vecchia, A.; Barberi, F.M.; Baroni, S.; Giannaccini, G.; Palego, L.; Massimetti, G.; Dell'Osso, L. Decreased Plasma Oxytocin Levels in Patients With PTSD. Front. Psychol. 2021, 12, 612338. [CrossRef]

52. Ozsoy, S.; Esel, E.; Kula, M. Serum oxytocin levels in patients with depression and the effects of gender and antidepressant treatment. Psychiatry Res. 2009, 169, 249-252. [CrossRef] [PubMed]

53. Frasch, A.; Zetzsche, T.; Steiger, A.; Jirikowski, G.F. Reduction of plasma oxytocin levels in patients suffering from major depression. Adv. Exp. Med. Biol. 1995, 395, 257-258.

54. Thul, T.A.; Corwin, E.J.; Carlson, N.S.; Brennan, P.A.; Young, L.J. Oxytocin and postpartum depression: A systematic review. Psychoneuroendocrinology 2020, 120, 104793. [CrossRef] [PubMed] 
55. Windle, R.J.; Shanks, N.; Lightman, S.L.; Ingram, C.D. Central oxytocin administration reduces stress-induced corticosterone release and anxiety behavior in rats. Endocrinology 1997, 138, 2829-2834. [CrossRef]

56. Windle, R.J.; Kershaw, Y.M.; Shanks, N.; Wood, S.A.; Lightman, S.L.; Ingram, C.D. Oxytocin attenuates stress-induced c-fos mRNA expression in specific forebrain regions associated with modulation of hypothalamo-pituitary-adrenal activity. J. Neurosci. 2004, 24, 2974-2982. [CrossRef] [PubMed]

57. Neumann, I.D.; Wigger, A.; Torner, L.; Holsboer, F.; Landgraf, R. Brain oxytocin inhibits basal and stress-induced activity of the hypothalamo-pituitary-adrenal axis in male and female rats: Partial action within the paraventricular nucleus. J. Neuroendocrinol. 2000, 12, 235-243. [CrossRef]

58. Cavanaugh, J.; Carp, S.B.; Rock, C.M.; French, J.A. Oxytocin modulates behavioral and physiological responses to a stressor in marmoset monkeys. Psychoneuroendocrinology 2016, 66, 22-30. [CrossRef]

59. Parker, K.J.; Buckmaster, C.L.; Schatzberg, A.F.; Lyons, D.M. Intranasal oxytocin administration attenuates the ACTH stress response in monkeys. Psychoneuroendocrinology 2005, 30, 924-929. [CrossRef]

60. Ditzen, B.; Schaer, M.; Gabriel, B.; Bodenmann, G.; Ehlert, U.; Heinrichs, M. Intranasal oxytocin increases positive communication and reduces cortisol levels during couple conflict. Biol. Psychiatry 2009, 65, 728-731. [CrossRef]

61. Norman, G.J.; Cacioppo, J.T.; Morris, J.S.; Malarkey, W.B.; Berntson, G.G.; Devries, A.C. Oxytocin increases autonomic cardiac control: Moderation by loneliness. Biol. Psychol. 2011, 86, 174-180. [CrossRef]

62. Quintana, D.S.; Kemp, A.H.; Alvares, G.A.; Guastella, A.J. A role for autonomic cardiac control in the effects of oxytocin on social behavior and psychiatric illness. Front. Neurosci. 2013, 7, 48. [CrossRef]

63. Kasahara, Y.; Sato, K.; Takayanagi, Y.; Mizukami, H.; Ozawa, K.; Hidema, S.; So, K.H.; Kawada, T.; Inoue, N.; Ikeda, I.; et al Oxytocin receptor in the hypothalamus is sufficient to rescue normal thermoregulatory function in male oxytocin receptor knockout mice. Endocrinology 2013, 154, 4305-4315. [CrossRef]

64. Takayanagi, Y.; Kasahara, Y.; Onaka, T.; Takahashi, N.; Kawada, T.; Nishimori, K. Oxytocin receptor-deficient mice developed late-onset obesity. Neuroreport 2008, 19, 951-955. [CrossRef] [PubMed]

65. Imami, A.S.; O’Donovan, S.M.; Creeden, J.F.; Wu, X.; Eby, H.; McCullumsmith, C.B.; Uvnäs-Moberg, K.; McCullumsmith, R.E.; Andari, E. Oxytocin's anti-inflammatory and proimmune functions in COVID-19: A transcriptomic signature-based approach. Physiol. Genom. 2020, 52, 401-407. [CrossRef] [PubMed]

66. Buemann, B.; Marazziti, D.; Uvnäs-Moberg, K. Can intravenous oxytocin infusion counteract hyperinflammation in COVID-19 infected patients? World J. Biol. Psychiatry 2021, 22, 387-398. [CrossRef] [PubMed]

67. Friuli, M.; Eramo, B.; Valenza, M.; Scuderi, C.; Provensi, G.; Romano, A. Targeting the Oxytocinergic System: A Possible Pharmacological Strategy for the Treatment of Inflammation Occurring in Different Chronic Diseases. Int. J. Mol. Sci. 2021, 22, 10250. [CrossRef]

68. Neumann, I.D.; Slattery, D.A. Oxytocin in General Anxiety and Social Fear: A Translational Approach. Biol. Psychiatry 2016, 79, 213-221. [CrossRef]

69. Baldi, E.; Costa, A.; Rani, B.; Passani, M.B.; Blandina, P.; Romano, A.; Provensi, G. Oxytocin and Fear Memory Extinction: Possible Implications for the Therapy of Fear Disorders? Int. J. Mol. Sci. 2021, 22, 10000. [CrossRef]

70. Janeček, M.; Dabrowska, J. Oxytocin facilitates adaptive fear and attenuates anxiety responses in animal models and human studies-potential interaction with the corticotropin-releasing factor (CRF) system in the bed nucleus of the stria terminalis (BNST). Cell Tissue Res. 2019, 375, 143-172. [CrossRef]

71. Amico, J.A.; Mantella, R.C.; Vollmer, R.R.; Li, X. Anxiety and stress responses in female oxytocin deficient mice. J. Neuroendocrinol. 2004, 16, 319-324. [CrossRef]

72. Yoshida, M.; Takayanagi, Y.; Inoue, K.; Kimura, T.; Young, L.J.; Onaka, T.; Nishimori, K. Evidence that oxytocin exerts anxiolytic effects via oxytocin receptor expressed in serotonergic neurons in mice. J. Neurosci. 2009, 29, 2259-2271. [CrossRef]

73. Heinrichs, M.; Baumgartner, T.; Kirschbaum, C.; Ehlert, U. Social support and oxytocin interact to suppress cortisol and subjective responses to psychosocial stress. Biol. Psychiatry 2003, 54, 1389-1398. [CrossRef]

74. Domes, G.; Heinrichs, M.; Gläscher, J.; Büchel, C.; Braus, D.F.; Herpertz, S.C. Oxytocin attenuates amygdala responses to emotional faces regardless of valence. Biol. Psychiatry 2007, 62, 1187-1190. [CrossRef]

75. Kanat, M.; Heinrichs, M.; Mader, I.; van Elst, L.T.; Domes, G. Oxytocin Modulates Amygdala Reactivity to Masked Fearful Eyes. Neuropsychopharmacology 2015, 40, 2632-2638. [CrossRef]

76. Kanat, M.; Heinrichs, M.; Schwarzwald, R.; Domes, G. Oxytocin attenuates neural reactivity to masked threat cues from the eyes. Neuropsychopharmacology 2015, 40, 287-295. [CrossRef]

77. Kirsch, P.; Esslinger, C.; Chen, Q.; Mier, D.; Lis, S.; Siddhanti, S.; Gruppe, H.; Mattay, V.S.; Gallhofer, B.; Meyer-Lindenberg, A. Oxytocin modulates neural circuitry for social cognition and fear in humans. J. Neurosci. 2005, 25, 11489-11493. [CrossRef] [PubMed]

78. Quintana, D.S.; Westlye, L.T.; Alnæs, D.; Rustan, Ø.G.; Kaufmann, T.; Smerud, K.T.; Mahmoud, R.A.; Djupesland, P.G.; Andreassen, O.A. Low dose intranasal oxytocin delivered with Breath Powered device dampens amygdala response to emotional stimuli: A peripheral effect-controlled within-subjects randomized dose-response fMRI trial. Psychoneuroendocrinology 2016, 69, 180-188. [CrossRef] [PubMed]

79. Kreuder, A.K.; Scheele, D.; Schultz, J.; Hennig, J.; Marsh, N.; Dellert, T.; Ettinger, U.; Philipsen, A.; Babasiz, M.; Herscheid, A.; et al. Common and dissociable effects of oxytocin and lorazepam on the neurocircuitry of fear. Proc. Natl. Acad. Sci. USA 2020, 117, 11781-11787. [CrossRef] [PubMed] 
80. Labuschagne, I.; Phan, K.L.; Wood, A.; Angstadt, M.; Chua, P.; Heinrichs, M.; Stout, J.C.; Nathan, P.J. Oxytocin attenuates amygdala reactivity to fear in generalized social anxiety disorder. Neuropsychopharmacology 2010, 35, 2403-2413. [CrossRef]

81. Holt-Lunstad, J.; Smith, T.B.; Layton, J.B. Social relationships and mortality risk: A meta-analytic review. PLoS Med. 2010, 7, e1000316. [CrossRef] [PubMed]

82. Meyer-Lindenberg, A.; Tost, H. Neural mechanisms of social risk for psychiatric disorders. Nat. Neurosci. 2012, 15, 663-668. [CrossRef]

83. Hostinar, C.E.; Sullivan, R.M.; Gunnar, M.R. Psychobiological mechanisms underlying the social buffering of the hypothalamicpituitary-adrenocortical axis: A review of animal models and human studies across development. Psychol. Bull. 2014, 140, 256-282. [CrossRef]

84. Smith, A.S.; Wang, Z. Hypothalamic oxytocin mediates social buffering of the stress response. Biol. Psychiatry 2014, 76, 281-288. [CrossRef] [PubMed]

85. Sicorello, M.; Dieckmann, L.; Moser, D.; Lux, V.; Luhmann, M.; Schlotz, W.; Kumsta, R. Oxytocin and the stress buffering effect of social company: A genetic study in daily life. Soc. Cogn. Affect. Neurosci. 2020, 15, 293-301. [CrossRef]

86. Burkett, J.P.; Andari, E.; Johnson, Z.V.; Curry, D.C.; de Waal, F.B.; Young, L.J. Oxytocin-dependent consolation behavior in rodents. Science 2016, 351, 375-378. [CrossRef]

87. Li, L.F.; Yuan, W.; He, Z.X.; Wang, L.M.; Jing, X.Y.; Zhang, J.; Yang, Y.; Guo, Q.Q.; Zhang, X.N.; Cai, W.Q.; et al. Involvement of oxytocin and GABA in consolation behavior elicited by socially defeated individuals in mandarin voles. Psychoneuroendocrinology 2019, 103, 14-24. [CrossRef] [PubMed]

88. Matsumoto, M.; Yoshida, M.; Jayathilake, B.W.; Inutsuka, A.; Nishimori, K.; Takayanagi, Y.; Onaka, T. Indispensable role of the oxytocin receptor for allogrooming toward socially distressed cage mates in female mice. J. Neuroendocrinol. 2021, 33, e12980. [CrossRef] [PubMed]

89. Scatliffe, N.; Casavant, S.; Vittner, D.; Cong, X. Oxytocin and early parent-infant interactions: A systematic review. Int. J. Nurs. Sci. 2019, 6, 445-453. [CrossRef] [PubMed]

90. Waldherr, M.; Neumann, I.D. Centrally released oxytocin mediates mating-induced anxiolysis in male rats. Proc. Natl. Acad. Sci. USA 2007, 104, 16681-16684. [CrossRef]

91. Phan, J.; Alhassen, L.; Argelagos, A.; Alhassen, W.; Vachirakorntong, B.; Lin, Z.; Sanathara, N.; Alachkar, A. Mating and parenting experiences sculpture mood-modulating effects of oxytocin-MCH signaling. Sci. Rep. 2020, 10, 13611. [CrossRef]

92. Detillion, C.E.; Craft, T.K.; Glasper, E.R.; Prendergast, B.J.; DeVries, A.C. Social facilitation of wound healing. Psychoneuroendocrinology 2004, 29, 1004-1011. [CrossRef]

93. Ditzen, B.; Heinrichs, M. Psychobiology of social support: The social dimension of stress buffering. Restor. Neurol. Neurosci. 2014, 32, 149-162. [CrossRef] [PubMed]

94. Chen, F.S.; Kumsta, R.; von Dawans, B.; Monakhov, M.; Ebstein, R.P.; Heinrichs, M. Common oxytocin receptor gene (OXTR) polymorphism and social support interact to reduce stress in humans. Proc. Natl. Acad. Sci. USA 2011, 108, 19937-19942. [CrossRef]

95. Kim, H.S.; Sherman, D.K.; Sasaki, J.Y.; Xu, J.; Chu, T.Q.; Ryu, C.; Suh, E.M.; Graham, K.; Taylor, S.E. Culture, distress, and oxytocin receptor polymorphism (OXTR) interact to influence emotional support seeking. Proc. Natl. Acad. Sci. USA 2010, 107, 15717-15721. [CrossRef] [PubMed]

96. Peters, S.; Slattery, D.A.; Uschold-Schmidt, N.; Reber, S.O.; Neumann, I.D. Dose-dependent effects of chronic central infusion of oxytocin on anxiety, oxytocin receptor binding and stress-related parameters in mice. Psychoneuroendocrinology 2014, 42, 225-236. [CrossRef]

97. Slattery, D.A.; Neumann, I.D. Chronic icv oxytocin attenuates the pathological high anxiety state of selectively bred Wistar rats. Neuropharmacology 2010, 58, 56-61. [CrossRef]

98. Bosch, O.J.; Neumann, I.D. Brain vasopressin is an important regulator of maternal behavior independent of dams' trait anxiety Proc. Natl. Acad. Sci. USA 2008, 105, 17139-17144. [CrossRef]

99. Guzmán, Y.F.; Tronson, N.C.; Jovasevic, V.; Sato, K.; Guedea, A.L.; Mizukami, H.; Nishimori, K.; Radulovic, J. Fear-enhancing effects of septal oxytocin receptors. Nat. Neurosci. 2013, 16, 1185-1187. [CrossRef]

100. Winter, J.; Meyer, M.; Berger, I.; Royer, M.; Bianchi, M.; Kuffner, K.; Peters, S.; Stang, S.; Langgartner, D.; Hartmann, F.; et al Chronic oxytocin-driven alternative splicing of Crfr2alpha induces anxiety (published online ahead of print, $25 \mathrm{May} 2021$ ). Mol. Psychiatry 2021. [CrossRef]

101. Fischer-Shofty, M.; Shamay-Tsoory, S.G.; Harari, H.; Levkovitz, Y. The effect of intranasal administration of oxytocin on fear recognition. Neuropsychologia 2010, 48, 179-184. [CrossRef]

102. Striepens, N.; Scheele, D.; Kendrick, K.M.; Becker, B.; Schäfer, L.; Schwalba, K.; Reul, J.; Maier, W.; Hurlemann, R. Oxytocin facilitates protective responses to aversive social stimuli in males. Proc. Natl. Acad. Sci. USA 2012, 109, 18144-18149. [CrossRef]

103. Domes, G.; Lischke, A.; Berger, C.; Grossmann, A.; Hauenstein, K.; Heinrichs, M.; Herpertz, S.C. Effects of intranasal oxytocin on emotional face processing in women. Psychoneuroendocrinology 2010, 35, 83-93. [CrossRef]

104. De Cagna, F.; Fusar-Poli, L.; Damiani, S.; Rocchetti, M.; Giovanna, G.; Mori, A.; Politi, P.; Brondino, N. The Role of Intranasal Oxytocin in Anxiety and Depressive Disorders: A Systematic Review of Randomized Controlled Trials. Clin. Psychopharmacol. Neurosci. 2019, 17, 1-11. [CrossRef] [PubMed]

105. Onaka, T.; Takayanagi, Y. The oxytocin system and early-life experience-dependent plastic changes. J. Neuroendocrinol. 2021, 33, e13049. [CrossRef] [PubMed] 
106. Grinevich, V.; Neumann, I.D. Brain oxytocin: How puzzle stones from animal studies translate into psychiatry. Mol. Psychiatry 2021, 26, 265-279. [CrossRef]

107. Sabihi, S.; Dong, S.M.; Maurer, S.D.; Post, C.; Leuner, B. Oxytocin in the medial prefrontal cortex attenuates anxiety: Anatomical and receptor specificity and mechanism of action. Neuropharmacology 2017, 125, 1-12. [CrossRef]

108. Li, K.; Nakajima, M.; Ibañez-Tallon, I.; Heintz, N. A Cortical Circuit for Sexually Dimorphic Oxytocin-Dependent Anxiety Behaviors. Cell 2016, 167, 60-72.e11. [CrossRef]

109. He, Z.; Young, L.; Ma, X.M.; Guo, Q.; Wang, L.; Yang, Y.; Luo, L.; Yuan, W.; Li, L.; Zhang, J.; et al. Increased anxiety and decreased sociability induced by paternal deprivation involve the PVN-PrL OTergic pathway. Elife 2019, 8, e44026. [CrossRef]

110. Lahoud, N.; Maroun, M. Oxytocinergic manipulations in corticolimbic circuit differentially affect fear acquisition and extinction. Psychoneuroendocrinology 2013, 38, 2184-2195. [CrossRef]

111. Brill-Maoz, N.; Maroun, M. Extinction of fear is facilitated by social presence: Synergism with prefrontal oxytocin. Psychoneuroendocrinology 2016, 66, 75-81. [CrossRef] [PubMed]

112. Li, X.H.; Matsuura, T.; Xue, M.; Chen, Q.Y.; Liu, R.H.; Lu, J.S.; Shi, W.; Fan, K.; Zhou, Z.; Miao, Z.; et al. Oxytocin in the anterior cingulate cortex attenuates neuropathic pain and emotional anxiety by inhibiting presynaptic long-term potentiation. Cell Rep. 2021, 36, 109411. [CrossRef]

113. Luo, L.; Becker, B.; Geng, Y.; Zhao, Z.; Gao, S.; Zhao, W.; Yao, S.; Zheng, X.; Ma, X.; Gao, Z.; et al. Sex-dependent neural effect of oxytocin during subliminal processing of negative emotion faces. Neuroimage 2017, 162, 127-137. [CrossRef]

114. Martinon, D.; Lis, P.; Roman, A.N.; Tornesi, P.; Applebey, S.V.; Buechner, G.; Olivera, V.; Dabrowska, J. Oxytocin receptors in the dorsolateral bed nucleus of the stria terminalis (BNST) bias fear learning toward temporally predictable cued fear. Transl. Psychiatry 2019, 9, 140. [CrossRef]

115. Moaddab, M.; Dabrowska, J. Oxytocin receptor neurotransmission in the dorsolateral bed nucleus of the stria terminalis facilitates the acquisition of cued fear in the fear-potentiated startle paradigm in rats. Neuropharmacology 2017, 121, 130-139. [CrossRef] [PubMed]

116. Duque-Wilckens, N.; Torres, L.Y.; Yokoyama, S.; Minie, V.A.; Tran, A.M.; Petkova, S.P.; Hao, R.; Ramos-Maciel, S.; Rios, R.A.; Jackson, K.; et al. Extrahypothalamic oxytocin neurons drive stress-induced social vigilance and avoidance. Proc. Natl. Acad. Sci. USA 2020, 117, 26406-26413. [CrossRef]

117. Blume, A.; Bosch, O.J.; Miklos, S.; Torner, L.; Wales, L.; Waldherr, M.; Neumann, I.D. Oxytocin reduces anxiety via ERK1/2 activation: Local effect within the rat hypothalamic paraventricular nucleus. Eur. J. Neurosci. 2008, 27, 1947-1956. [CrossRef] [PubMed]

118. Smith, A.S.; Tabbaa, M.; Lei, K.; Eastham, P.; Butler, M.J.; Linton, L.; Altshuler, R.; Liu, Y.; Wang, Z. Local oxytocin tempers anxiety by activating GABAA receptors in the hypothalamic paraventricular nucleus. Psychoneuroendocrinology 2016, 63, 50-58. [CrossRef]

119. Pati, D.; Harden, S.W.; Sheng, W.; Kelly, K.B.; de Kloet, A.D.; Krause, E.G.; Frazier, C.J. Endogenous oxytocin inhibits hypothalamic corticotrophin-releasing hormone neurones following acute hypernatraemia. J. Neuroendocrinol. 2020, 32, e12839. [CrossRef] [PubMed]

120. Grillon, C.; Krimsky, M.; Charney, D.R.; Vytal, K.; Ernst, M.; Cornwell, B. Oxytocin increases anxiety to unpredictable threat. Mol. Psychiatry 2013, 18, 958-960. [CrossRef]

121. Huang, T.; Guan, F.; Licinio, J.; Wong, M.L.; Yang, Y. Activation of septal OXTr neurons induces anxiety- but not depressive-like behaviors (published online ahead of print, 6 September 2021). Mol. Psychiatry 2021. [CrossRef]

122. Zoicas, I.; Slattery, D.A.; Neumann, I.D. Brain oxytocin in social fear conditioning and its extinction: Involvement of the lateral septum. Neuropsychopharmacology 2014, 39, 3027-3035. [CrossRef]

123. Menon, R.; Grund, T.; Zoicas, I.; Althammer, F.; Fiedler, D.; Biermeier, V.; Bosch, O.J.; Hiraoka, Y.; Nishimori, K.; Eliava, M.; et al. Oxytocin Signaling in the Lateral Septum Prevents Social Fear during Lactation. Curr. Biol. 2018, 28, 1066-1078.e6. [CrossRef]

124. Han, R.T.; Kim, Y.B.; Park, E.H.; Kim, J.Y.; Ryu, C.; Kim, H.Y.; Lee, J.; Pahk, K.; Shanyu, C.; Kim, H.; et al. Long-Term Isolation Elicits Depression and Anxiety-Related Behaviors by Reducing Oxytocin-Induced GABAergic Transmission in Central Amygdala. Front. Mol. Neurosci. 2018, 11, 246. [CrossRef]

125. Bale, T.L.; Davis, A.M.; Auger, A.P.; Dorsa, D.M.; McCarthy, M.M. CNS region-specific oxytocin receptor expression: Importance in regulation of anxiety and sex behavior. J. Neurosci. 2001, 21, 2546-2552. [CrossRef] [PubMed]

126. Knobloch, H.S.; Charlet, A.; Hoffmann, L.C.; Eliava, M.; Khrulev, S.; Cetin, A.H.; Osten, P.; Schwarz, M.K.; Seeburg, P.H.; Stoop, R.; et al. Evoked axonal oxytocin release in the central amygdala attenuates fear response. Neuron 2012, 73, 553-566. [CrossRef] [PubMed]

127. Viviani, D.; Charlet, A.; van den Burg, E.; Robinet, C.; Hurni, N.; Abatis, M.; Magara, F.; Stoop, R. Oxytocin selectively gates fear responses through distinct outputs from the central amygdala. Science 2011, 333, 104-107. [CrossRef] [PubMed]

128. Rickenbacher, E.; Perry, R.E.; Sullivan, R.M.; Moita, M.A. Freezing suppression by oxytocin in central amygdala allows alternate defensive behaviours and mother-pup interactions. Elife 2017, 6, e24080. [CrossRef]

129. Ferretti, V.; Maltese, F.; Contarini, G.; Nigro, M.; Bonavia, A.; Huang, H.; Gigliucci, V.; Morelli, G.; Scheggia, D.; Managò, F.; et al. Oxytocin Signaling in the Central Amygdala Modulates Emotion Discrimination in Mice. Curr. Biol. 2019, 29, 1938-1953.e6. [CrossRef]

130. Pagani, J.H.; Williams Avram, S.K.; Cui, Z.; Song, J.; Mezey, É.; Senerth, J.M.; Baumann, M.H.; Young, W.S. Raphe serotonin neuron-specific oxytocin receptor knockout reduces aggression without affecting anxiety-like behavior in male mice only. Genes Brain Behav. 2015, 14, 167-176. [CrossRef] [PubMed]

131. Jiang, Y.; Travagli, R.A. Hypothalamic-vagal oxytocinergic neurocircuitry modulates gastric emptying and motility following stress. J. Physiol. 2020, 598, 4941-4955. [CrossRef] [PubMed] 
132. Schulkin, J.; Sterling, P. Allostasis: A Brain-Centered, Predictive Mode of Physiological Regulation. Trends Neurosci. 2019, 42, 740-752. [CrossRef]

133. Ferris, C.F.; Foote, K.B.; Meltser, H.M.; Plenby, M.G.; Smith, K.L.; Insel, T.R. Oxytocin in the amygdala facilitates maternal aggression. Ann. N. Y. Acad. Sci. 1992, 652, 456-457. [CrossRef]

134. De Dreu, C.K. Oxytocin modulates cooperation within and competition between groups: An integrative review and research agenda. Horm. Behav. 2012, 61, 419-428. [CrossRef]

135. Stallen, M.; De Dreu, C.K.; Shalvi, S.; Smidts, A.; Sanfey, A.G. The herding hormone: Oxytocin stimulates in-group conformity. Psychol. Sci. 2012, 23, 1288-1292. [CrossRef]

136. Zhang, H.; Gross, J.; De Dreu, C.; Ma, Y. Oxytocin promotes coordinated out-group attack during intergroup conflict in humans. Elife 2019, 8, e40698. [CrossRef]

137. Schaller, F.; Watrin, F.; Sturny, R.; Massacrier, A.; Szepetowski, P.; Muscatelli, F. A single postnatal injection of oxytocin rescues the lethal feeding behaviour in mouse newborns deficient for the imprinted Magel2 gene. Hum. Mol. Genet. 2010, 19, 4895-4905. [CrossRef] [PubMed]

138. Quintana, D.S.; Guastella, A.J. An Allostatic Theory of Oxytocin. Trends Cogn. Sci. 2020, 24, 515-528. [CrossRef] [PubMed]

139. Grinevich, V.; Stoop, R. Interplay between Oxytocin and Sensory Systems in the Orchestration of Socio-Emotional Behaviors. Neuron 2018, 99, 887-904. [CrossRef] [PubMed]

140. Oettl, L.L.; Ravi, N.; Schneider, M.; Scheller, M.F.; Schneider, P.; Mitre, M.; da Silva Gouveia, M.; Froemke, R.C.; Chao, M.V.; Young, W.S.; et al. Oxytocin Enhances Social Recognition by Modulating Cortical Control of Early Olfactory Processing. Neuron 2016, 90, 609-621. [CrossRef]

141. Marlin, B.J.; Mitre, M.; D'amour J, A.; Chao, M.V.; Froemke, R.C. Oxytocin enables maternal behaviour by balancing cortical inhibition. Nature 2015, 520, 499-504. [CrossRef] [PubMed]

142. Kapetaniou, G.E.; Reinhard, M.A.; Christian, P.; Jobst, A.; Tobler, P.N.; Padberg, F.; Soutschek, A. The role of oxytocin in delay of gratification and flexibility in non-social decision making. Elife 2021, 10, e61844. [CrossRef] [PubMed]

143. Roberts, B.Z.; Young, J.W.; He, Y.V.; Cope, Z.A.; Shilling, P.D.; Feifel, D. Oxytocin improves probabilistic reversal learning but not effortful motivation in Brown Norway rats. Neuropharmacology 2019, 150, 15-26. [CrossRef] [PubMed]

144. Sala, M.; Braida, D.; Lentini, D.; Busnelli, M.; Bulgheroni, E.; Capurro, V.; Finardi, A.; Donzelli, A.; Pattini, L.; Rubino, T.; et al. Pharmacologic rescue of impaired cognitive flexibility, social deficits, increased aggression, and seizure susceptibility in oxytocin receptor null mice: A neurobehavioral model of autism. Biol. Psychiatry 2011, 69, 875-882. [CrossRef]

145. Eckstein, M.; Scheele, D.; Patin, A.; Preckel, K.; Becker, B.; Walter, A.; Domschke, K.; Grinevich, V.; Maier, W.; Hurlemann, R. Oxytocin Facilitates Pavlovian Fear Learning in Males. Neuropsychopharmacology 2016, 41, 932-939. [CrossRef] [PubMed]

146. Terburg, D.; Scheggia, D.; Triana Del Rio, R.; Klumpers, F.; Ciobanu, A.C.; Morgan, B.; Montoya, E.R.; Bos, P.A.; Giobellina, G.; van den Burg, E.H.; et al. The Basolateral Amygdala Is Essential for Rapid Escape: A Human and Rodent Study. Cell 2018, 175, 723-735.e16. [CrossRef]

147. Robinson, D.A.; Wei, F.; Wang, G.D.; Li, P.; Kim, S.J.; Vogt, S.K.; Muglia, L.J.; Zhuo, M. Oxytocin mediates stress-induced analgesia in adult mice. J. Physiol. 2002, 540, 593-606. [CrossRef]

148. Li, Y.X.; An, H.; Wen, Z;; Tao, Z.Y.; Cao, D.Y. Can oxytocin inhibit stress-induced hyperalgesia? Neuropeptides 2020, 79, 101996. [CrossRef]

149. Rash, J.A.; Aguirre-Camacho, A.; Campbell, T.S. Oxytocin and pain: A systematic review and synthesis of findings. Clin. J. Pain 2014, 30, 453-462. [CrossRef]

150. Mazzuca, M.; Minlebaev, M.; Shakirzyanova, A.; Tyzio, R.; Taccola, G.; Janackova, S.; Gataullina, S.; Ben-Ari, Y.; Giniatullin, R.; Khazipov, R. Newborn Analgesia Mediated by Oxytocin during Delivery. Front. Cell. Neurosci. 2011, 5, 3. [CrossRef]

151. Tyzio, R.; Cossart, R.; Khalilov, I.; Minlebaev, M.; Hubner, C.A.; Represa, A.; Ben-Ari, Y.; Khazipov, R. Maternal oxytocin triggers a transient inhibitory switch in GABA signaling in the fetal brain during delivery. Science 2006, 314, 1788-1792. [CrossRef]

152. Bosch, O.J. Maternal aggression in rodents: Brain oxytocin and vasopressin mediate pup defence. Philos. Trans. R. Soc. B Biol. Sci. 2013, 368, 20130085. [CrossRef] [PubMed]

153. Srisawat, R.; Ludwig, M.; Bull, P.M.; Douglas, A.J.; Russell, J.A.; Leng, G. Nitric oxide and the oxytocin system in pregnancy. J. Neurosci. 2000, 20, 6721-6727. [CrossRef] [PubMed]

154. Brunton, P.J.; Bales, J.; Russell, J.A. Allopregnanolone and induction of endogenous opioid inhibition of oxytocin responses to immune stress in pregnant rats. J. Neuroendocrinol. 2012, 24, 690-700. [CrossRef]

155. Leng, G.; Russell, J.A. The osmoresponsiveness of oxytocin and vasopressin neurones: Mechanisms, allostasis and evolution. J. Neuroendocrinol. 2019, 31, e12662. [CrossRef]

156. Armstrong, W.E.; Hatton, G.I. The puzzle of pulsatile oxytocin secretion during lactation: Some new pieces. Am. J. Physiol. Integr. Comp. Physiol. 2006, 291, R26-R28. [CrossRef] [PubMed]

157. Uvnäs-Moberg, K.; Prime, D.K. Oxytocin effects in mothers and infants during breastfeeding. Infant 2013, 9, $201-206$.

158. Zhang, G.; Cai, D. Circadian intervention of obesity development via resting-stage feeding manipulation or oxytocin treatment. Am. J. Physiol. Endocrinol. Metab. 2011, 301, E1004-E1012. [CrossRef]

159. Yamashita, M.; Takayanagi, Y.; Yoshida, M.; Nishimori, K.; Kusama, M.; Onaka, T. Involvement of prolactin-releasing peptide in the activation of oxytocin neurones in response to food intake. J. Neuroendocrinol. 2013, 25, 455-465. [CrossRef] [PubMed] 
160. Jiang, Y.; Coleman, F.H.; Kopenhaver Doheny, K.; Travagli, R.A. Stress Adaptation Upregulates Oxytocin within HypothalamoVagal Neurocircuits. Neuroscience 2018, 390, 198-205. [CrossRef]

161. Babić, R.; Babić, M.; Rastović, P.; Ćurlin, M.; Šimić, J.; Mandić, K.; Pavlović, K. Resilience in Health and Illness. Psychiatr. Danub. 2020, 32, 226-232.

162. Sharma, S.R.; Gonda, X.; Dome, P.; Tarazi, F.I. What's Love Got to do with it: Role of oxytocin in trauma, attachment and resilience. Pharmacol. Ther. 2020, 214, 107602. [CrossRef] [PubMed]

163. Cathomas, F.; Murrough, J.W.; Nestler, E.J.; Han, M.H.; Russo, S.J. Neurobiology of Resilience: Interface Between Mind and Body. Biol. Psychiatry 2019, 86, 410-420. [CrossRef]

164. Feldman, R. What is resilience: An affiliative neuroscience approach. World Psychiatry 2020, 19, 132-150. [CrossRef]

165. Walker, S.C.; Cavieres, A.; Peñaloza-Sancho, V.; El-Deredy, W.; McGlone, F.P.; Dagnino-Subiabre, A. C-low threshold mechanoafferent targeted dynamic touch modulates stress resilience in rats exposed to chronic mild stress (published online ahead of print, 27 August 2020). Eur. J. Neurosci. 2020. [CrossRef]

166. Okabe, S.; Yoshida, M.; Takayanagi, Y.; Onaka, T. Activation of hypothalamic oxytocin neurons following tactile stimuli in rats. Neurosci. Lett. 2015, 600, 22-27. [CrossRef] [PubMed]

167. Okabe, S.; Takayanagi, Y.; Yoshida, M.; Onaka, T. Gentle stroking stimuli induce affiliative responsiveness to humans in male rats Sci. Rep. 2020, 10, 9135. [CrossRef]

168. Okabe, S.; Takayanagi, Y.; Yoshida, M.; Onaka, T. Post-weaning stroking stimuli induce affiliative behavior toward humans and influence brain activity in female rats. Sci. Rep. 2021, 11, 3805. [CrossRef]

169. Faraji, J.; Karimi, M.; Soltanpour, N.; Moharrerie, A.; Rouhzadeh, Z.; Lotfi, H.; Hosseini, S.A.; Jafari, S.Y.; Roudaki, S.; Moeeini, R.; et al Oxytocin-mediated social enrichment promotes longer telomeres and novelty seeking. Elife 2018, 7, e40262. [CrossRef]

170. Wood, S.K. Individual differences in the neurobiology of social stress: Implications for depression-cardiovascular disease comorbidity. Curr. Neuropharmacol. 2014, 12, 205-211. [CrossRef] [PubMed]

171. Calpe-López, C.; García-Pardo, M.P.; Martínez-Caballero, M.A.; Santos-Ortíz, A.; Aguilar, M.A. Behavioral Traits Associated With Resilience to the Effects of Repeated Social Defeat on Cocaine-Induced Conditioned Place Preference in Mice. Front. Behav. Neurosci. 2019, 13, 278. [CrossRef]

172. Shi, D.D.; Zhang, Y.D.; Ren, Y.Y.; Peng, S.Y.; Yuan, T.F.; Wang, Z. Predictable maternal separation confers adult stress resilience via the medial prefrontal cortex oxytocin signaling pathway in rats (published online ahead of print, 24 September 2021). Mol. Psychiatry 2021. [CrossRef]

173. Bardo, M.T.; Hammerslag, L.R.; Malone, S.G. Effect of early life social adversity on drug abuse vulnerability: Focus on corticotropin-releasing factor and oxytocin. Neuropharmacology 2021, 191, 108567. [CrossRef] [PubMed]

174. Barrett, C.E.; Arambula, S.E.; Young, L.J. The oxytocin system promotes resilience to the effects of neonatal isolation on adult social attachment in female prairie voles. Transl. Psychiatry 2015, 5, e606. [CrossRef] [PubMed]

175. Mairesse, J.; Zinni, M.; Pansiot, J.; Hassan-Abdi, R.; Demene, C.; Colella, M.; Charriaut-Marlangue, C.; Rideau Batista Novais, A.; Tanter, M.; Maccari, S.; et al. Oxytocin receptor agonist reduces perinatal brain damage by targeting microglia. Glia 2019, 67, 345-359. [CrossRef]

176. Amini-Khoei, H.; Mohammadi-Asl, A.; Amiri, S.; Hosseini, M.J.; Momeny, M.; Hassanipour, M.; Rastegar, M.; Haj-Mirzaian, A.; Mirzaian, A.H.; Sanjarimoghaddam, H.; et al. Oxytocin mitigated the depressive-like behaviors of maternal separation stress through modulating mitochondrial function and neuroinflammation. Prog. Neuro-Psychopharmacol. Biol. Psychiatry 2017, 76, 169-178. [CrossRef]

177. Ji, H.; Su, W.; Zhou, R.; Feng, J.; Lin, Y.; Zhang, Y.; Wang, X.; Chen, X.; Li, J. Intranasal oxytocin administration improves depression-like behaviors in adult rats that experienced neonatal maternal deprivation. Behav. Pharmacol. 2016, 27, 689-696. [CrossRef]

178. Mansouri, M.; Pouretemad, H.; Roghani, M.; Wegener, G.; Ardalan, M. Autistic-like behaviours and associated brain structural plasticity are modulated by oxytocin in maternally separated rats. Behav. Brain Res. 2020, 393, 112756. [CrossRef] [PubMed]

179. Joushi, S.; Esmaeilpour, K.; Masoumi-Ardakani, Y.; Esmaeili-Mahani, S.; Sheibani, V. Intranasal oxytocin administration facilitates the induction of long-term potentiation and promotes cognitive performance of maternally separated rats. Psychoneuroendocrinology 2021, 123, 105044. [CrossRef]

180. Reguilón, M.D.; Ferrer-Pérez, C.; Miñarro, J.; Rodríguez-Arias, M. Oxytocin reverses ethanol consumption and neuroinflammation induced by social defeat in male mice. Horm. Behav. 2021, 127, 104875. [CrossRef]

181. Lestanova, Z.; Bacova, Z.; Kiss, A.; Havranek, T.; Strbak, V.; Bakos, J. Oxytocin Increases Neurite Length and Expression of Cytoskeletal Proteins Associated with Neuronal Growth. J. Mol. Neurosci. 2016, 59, 184-192. [CrossRef]

182. Filova, B.; Reichova, A.; Zatkova, M.; Srancikova, A.; Bukatova, S.; Bacova, Z.; Bakos, J. Expression of synaptic proteins in the hippocampus is modulated by neonatal oxytocin treatment. Neurosci. Lett. 2020, 725, 134912. [CrossRef]

183. Lin, Y.T.; Chen, C.C.; Huang, C.C.; Nishimori, K.; Hsu, K.S. Oxytocin stimulates hippocampal neurogenesis via oxytocin receptor expressed in CA3 pyramidal neurons. Nat. Commun. 2017, 8, 537. [CrossRef]

184. Bertoni, A.; Schaller, F.; Tyzio, R.; Gaillard, S.; Santini, F.; Xolin, M.; Diabira, D.; Vaidyanathan, R.; Matarazzo, V.; Medina, I.; et al. Oxytocin administration in neonates shapes hippocampal circuitry and restores social behavior in a mouse model of autism (published online ahead of print, 21 July 2021). Mol. Psychiatry 2021. [CrossRef] 
185. Ferrer-Pérez, C.; Reguilón, M.D.; Manzanedo, C.; Miñarro, J.; Rodríguez-Arias, M. Social Housing Conditions Modulate the Long-Lasting Increase in Cocaine Reward Induced by Intermittent Social Defeat. Front. Behav. Neurosci. 2019, 13, 148. [CrossRef] [PubMed]

186. Ferrer-Pérez, C.; Reguilón, M.D.; Miñarro, J.; Rodríguez-Arias, M. Endogenous oxytocin is essential for the buffering effects of pair housing against the increase in cocaine reward induced by social stress. Physiol. Behav. 2020, 221, 112913. [CrossRef]

187. Hansson, A.C.; Koopmann, A.; Uhrig, S.; Bühler, S.; Domi, E.; Kiessling, E.; Ciccocioppo, R.; Froemke, R.C.; Grinevich, V.; Kiefer, F.; et al. Oxytocin Reduces Alcohol Cue-Reactivity in Alcohol-Dependent Rats and Humans. Neuropsychopharmacology 2018, 43, 1235-1246. [CrossRef] [PubMed]

188. Tunstall, B.J.; Kirson, D.; Zallar, L.J.; McConnell, S.A.; Vendruscolo, J.C.M.; Ho, C.P.; Oleata, C.S.; Khom, S.; Manning, M.; Lee, M.R.; et al. Oxytocin blocks enhanced motivation for alcohol in alcohol dependence and blocks alcohol effects on GABAergic transmission in the central amygdala. PLoS Biol. 2019, 17, e2006421. [CrossRef]

189. Le Dorze, C.; Borreca, A.; Pignataro, A.; Ammassari-Teule, M.; Gisquet-Verrier, P. Emotional remodeling with oxytocin durably rescues trauma-induced behavioral and neuro-morphological changes in rats: A promising treatment for PTSD. Transl. Psychiatry 2020, 10, 27. [CrossRef] [PubMed]

190. Nair, H.P.; Gutman, A.R.; Davis, M.; Young, L.J. Central oxytocin, vasopressin, and corticotropin-releasing factor receptor densities in the basal forebrain predict isolation potentiated startle in rats. J. Neurosci. 2005, 25, 11479-11488. [CrossRef]

191. Opacka-Juffry, J.; Mohiyeddini, C. Experience of stress in childhood negatively correlates with plasma oxytocin concentration in adult men. Stress 2012, 15, 1-10. [CrossRef] [PubMed]

192. Bertsch, K.; Schmidinger, I.; Neumann, I.D.; Herpertz, S.C. Reduced plasma oxytocin levels in female patients with borderline personality disorder. Horm. Behav. 2013, 63, 424-429. [CrossRef] [PubMed]

193. Müller, L.E.; Bertsch, K.; Bülau, K.; Herpertz, S.C.; Buchheim, A. Emotional neglect in childhood shapes social dysfunctioning in adults by influencing the oxytocin and the attachment system: Results from a population-based study. Int. J. Psychophysiol. 2019, 136, 73-80. [CrossRef]

194. Young Kuchenbecker, S.; Pressman, S.D.; Celniker, J.; Grewen, K.M.; Sumida, K.D.; Jonathan, N.; Everett, B.; Slavich, G.M. Oxytocin, cortisol, and cognitive control during acute and naturalistic stress. Stress 2021, 24, 370-383. [CrossRef] [PubMed]

195. Priel, A.; Djalovski, A.; Zagoory-Sharon, O.; Feldman, R. Maternal depression impacts child psychopathology across the first decade of life: Oxytocin and synchrony as markers of resilience. J. Child Psychol. Psychiatry 2019, 60, 30-42. [CrossRef] [PubMed]

196. Feldman, R.; Vengrober, A.; Ebstein, R.P. Affiliation buffers stress: Cumulative genetic risk in oxytocin-vasopressin genes combines with early caregiving to predict PTSD in war-exposed young children. Transl. Psychiatry 2014, 4, e370. [CrossRef]

197. Brüne, M. Does the oxytocin receptor (OXTR) polymorphism (rs2254298) confer 'vulnerability' for psychopathology or 'differential susceptibility'? Insights from evolution. BMC Med. 2012, 10, 38. [CrossRef]

198. Thompson, R.J.; Parker, K.J.; Hallmayer, J.F.; Waugh, C.E.; Gotlib, I.H. Oxytocin receptor gene polymorphism (rs2254298) interacts with familial risk for psychopathology to predict symptoms of depression and anxiety in adolescent girls. Psychoneuroendocrinology 2011, 36, 144-147. [CrossRef]

199. Womersley, J.S.; Hemmings, S.M.J.; Ziegler, C.; Gutridge, A.; Ahmed-Leitao, F.; Rosenstein, D.; Domschke, K.; Seedat, S. Childhood emotional neglect and oxytocin receptor variants: Association with limbic brain volumes. World J. Biol. Psychiatry 2020, 21, 513-528. [CrossRef] [PubMed]

200. McQuaid, R.J.; McInnis, O.A.; Stead, J.D.; Matheson, K.; Anisman, H. A paradoxical association of an oxytocin receptor gene polymorphism: Early-life adversity and vulnerability to depression. Front. Neurosci. 2013, 7, 128. [CrossRef]

201. Bradley, B.; Westen, D.; Mercer, K.B.; Binder, E.B.; Jovanovic, T.; Crain, D.; Wingo, A.; Heim, C. Association between childhood maltreatment and adult emotional dysregulation in a low-income, urban, African American sample: Moderation by oxytocin receptor gene. Dev. Psychopathol. 2011, 23, 439-452. [CrossRef]

202. Hostinar, C.E.; Cicchetti, D.; Rogosch, F.A. Oxytocin receptor gene polymorphism, perceived social support, and psychological symptoms in maltreated adolescents. Dev. Psychopathol. 2014, 26, 465-477. [CrossRef] [PubMed]

203. Bradley, B.; Davis, T.A.; Wingo, A.P.; Mercer, K.B.; Ressler, K.J. Family environment and adult resilience: Contributions of positive parenting and the oxytocin receptor gene. Eur. J. Psychotraumatol. 2013, 4, 21659. [CrossRef]

204. Sippel, L.M.; Han, S.; Watkins, L.E.; Harpaz-Rotem, I.; Southwick, S.M.; Krystal, J.H.; Olff, M.; Sherva, R.; Farrer, L.A.; Kranzler, H.R.; et al. Oxytocin receptor gene polymorphisms, attachment, and PTSD: Results from the National Health and Resilience in Veterans Study. J. Psychiatr. Res. 2017, 94, 139-147. [CrossRef]

205. Malhi, G.S.; Das, P.; Outhred, T.; Dobson-Stone, C.; Bell, E.; Gessler, D.; Bryant, R.; Mannie, Z. Interactions of OXTR rs53576 and emotional trauma on hippocampal volumes and perceived social support in adolescent girls. Psychoneuroendocrinology 2020, 115, 104635. [CrossRef]

206. Milaniak, I.; Cecil, C.A.M.; Barker, E.D.; Relton, C.L.; Gaunt, T.R.; McArdle, W.; Jaffee, S.R. Variation in DNA methylation of the oxytocin receptor gene predicts children's resilience to prenatal stress. Dev. Psychopathol. 2017, 29, 1663-1674. [CrossRef] [PubMed]

207. Bowen, M.T.; Neumann, I.D. Rebalancing the Addicted Brain: Oxytocin Interference with the Neural Substrates of Addiction. Trends Neurosci. 2017, 40, 691-708. [CrossRef] [PubMed]

208. King, C.E.; Gano, A.; Becker, H.C. The role of oxytocin in alcohol and drug abuse. Brain Res. 2020, 1736, 146761. [CrossRef]

209. Joseph, J.E.; McRae-Clark, A.; Sherman, B.J.; Baker, N.L.; Moran-Santa Maria, M.; Brady, K.T. Neural correlates of oxytocin and cue reactivity in cocaine-dependent men and women with and without childhood trauma. Psychopharmacology 2020, 237, 249-261. [CrossRef] 
210. Eidelman-Rothman, M.; Goldstein, A.; Levy, J.; Weisman, O.; Schneiderman, I.; Mankuta, D.; Zagoory-Sharon, O.; Feldman, R. Oxytocin affects spontaneous neural oscillations in trauma-exposed war veterans. Front. Behav. Neurosci. 2015, 9, 165. [CrossRef]

211. van Zuiden, M.; Frijling, J.L.; Nawijn, L.; Koch, S.B.J.; Goslings, J.C.; Luitse, J.S.; Biesheuvel, T.H.; Honig, A.; Veltman, D.J.; Olff, M. Intranasal Oxytocin to Prevent Posttraumatic Stress Disorder Symptoms: A Randomized Controlled Trial in Emergency Department Patients. Biol. Psychiatry 2017, 81, 1030-1040. [CrossRef]

212. Sack, M.; Spieler, D.; Wizelman, L.; Epple, G.; Stich, J.; Zaba, M.; Schmidt, U. Intranasal oxytocin reduces provoked symptoms in female patients with posttraumatic stress disorder despite exerting sympathomimetic and positive chronotropic effects in a randomized controlled trial. BMC Med. 2017, 15, 40. [CrossRef]

213. Grimm, S.; Pestke, K.; Feeser, M.; Aust, S.; Weigand, A.; Wang, J.; Wingenfeld, K.; Pruessner, J.C.; La Marca, R.; Böker, H.; et al. Early life stress modulates oxytocin effects on limbic system during acute psychosocial stress. Soc. Cogn. Affect. Neurosci. 2014, 9, 1828-1835. [CrossRef]

214. MacDonald, E.; Dadds, M.R.; Brennan, J.L.; Williams, K.; Levy, F.; Cauchi, A.J. A review of safety, side-effects and subjective reactions to intranasal oxytocin in human research. Psychoneuroendocrinology 2011, 36, 1114-1126. [CrossRef]

215. Verhees, M.; Houben, J.; Ceulemans, E.; Bakermans-Kranenburg, M.J.; van, I.M.H.; Bosmans, G. No side-effects of single intranasal oxytocin administration in middle childhood. Psychopharmacology 2018, 235, 2471-2477. [CrossRef]

216. Cai, Q.; Feng, L.; Yap, K.Z. Systematic review and meta-analysis of reported adverse events of long-term intranasal oxytocin treatment for autism spectrum disorder. Psychiatry Clin. Neurosci. 2018, 72, 140-151. [CrossRef]

217. Bowen, M.T.; McGregor, I.S. Oxytocin and vasopressin modulate the social response to threat: A preclinical study. Int. J. Neuropsychopharmacol. 2014, 17, 1621-1633. [CrossRef] [PubMed]

218. Hicks, C.; Ramos, L.; Reekie, T.; Misagh, G.H.; Narlawar, R.; Kassiou, M.; McGregor, I.S. Body temperature and cardiac changes induced by peripherally administered oxytocin, vasopressin and the non-peptide oxytocin receptor agonist WAY 267,464: A biotelemetry study in rats. Br. J. Pharmacol. 2014, 171, 2868-2887. [CrossRef]

219. Ramos, L.; Hicks, C.; Kevin, R.; Caminer, A.; Narlawar, R.; Kassiou, M.; McGregor, I.S. Acute prosocial effects of oxytocin and vasopressin when given alone or in combination with 3,4-methylenedioxymethamphetamine in rats: Involvement of the V1A receptor. Neuropsychopharmacology 2013, 38, 2249-2259. [CrossRef] [PubMed]

220. Song, Z.; McCann, K.E.; McNeill, J.K. 4th.; Larkin, T.E., 2nd; Huhman, K.L.; Albers, H.E. Oxytocin induces social communication by activating arginine-vasopressin V1a receptors and not oxytocin receptors. Psychoneuroendocrinology 2014, 50, 14-19. [CrossRef] [PubMed]

221. Lee, M.R.; Scheidweiler, K.B.; Diao, X.X.; Akhlaghi, F.; Cummins, A.; Huestis, M.A.; Leggio, L.; Averbeck, B.B. Oxytocin by intranasal and intravenous routes reaches the cerebrospinal fluid in rhesus macaques: Determination using a novel oxytocin assay. Mol. Psychiatry 2018, 23, 115-122. [CrossRef]

222. Neumann, I.D.; Maloumby, R.; Beiderbeck, D.I.; Lukas, M.; Landgraf, R. Increased brain and plasma oxytocin after nasal and peripheral administration in rats and mice. Psychoneuroendocrinology 2013, 38, 1985-1993. [CrossRef] [PubMed]

223. Striepens, N.; Kendrick, K.M.; Hanking, V.; Landgraf, R.; Wüllner, U.; Maier, W.; Hurlemann, R. Elevated cerebrospinal fluid and blood concentrations of oxytocin following its intranasal administration in humans. Sci. Rep. 2013, 3, 3440. [CrossRef]

224. Tzabazis, A.; Kori, S.; Mechanic, J.; Miller, J.; Pascual, C.; Manering, N.; Carson, D.; Klukinov, M.; Spierings, E.; Jacobs, D.; et al Oxytocin and Migraine Headache. Headache 2017, 57 (Suppl. 2), 64-75. [CrossRef] [PubMed]

225. Quintana, D.S.; Lischke, A.; Grace, S.; Scheele, D.; Ma, Y.; Becker, B. Advances in the field of intranasal oxytocin research: Lessons learned and future directions for clinical research. Mol. Psychiatry 2021, 26, 80-91. [CrossRef]

226. Leng, G.; Ludwig, M. Intranasal Oxytocin: Myths and Delusions. Biol. Psychiatry 2016, 79, 243-250. [CrossRef]

227. Ichinose, W.; Cherepanov, S.M.; Shabalova, A.A.; Yokoyama, S.; Yuhi, T.; Yamaguchi, H.; Watanabe, A.; Yamamoto, Y.; Okamoto, H.; Horike, S.; et al. Development of a Highly Potent Analogue and a Long-Acting Analogue of Oxytocin for the Treatment of Social Impairment-Like Behaviors. J. Med. Chem. 2019, 62, 3297-3310. [CrossRef]

228. Neumann, I.; Landgraf, R.; Takahashi, Y.; Pittman, Q.J.; Russell, J.A. Stimulation of oxytocin release within the supraoptic nucleus and into blood by CCK-8. Am. J. Physiol. 1994, 267, R1626-R1631. [CrossRef]

229. Sabatier, N.; Caquineau, C.; Dayanithi, G.; Bull, P.; Douglas, A.J.; Guan, X.M.; Jiang, M.; Van der Ploeg, L.; Leng, G. Alphamelanocyte-stimulating hormone stimulates oxytocin release from the dendrites of hypothalamic neurons while inhibiting oxytocin release from their terminals in the neurohypophysis. J. Neurosci. 2003, 23, 10351-10358. [CrossRef] [PubMed]

230. Takayanagi, Y.; Yoshida, M.; Takashima, A.; Takanami, K.; Yoshida, S.; Nishimori, K.; Nishijima, I.; Sakamoto, H.; Yamagata, T.; Onaka, T Activation of Supraoptic Oxytocin Neurons by Secretin Facilitates Social Recognition. Biol. Psychiatry 2017, 81, 243-251. [CrossRef]

231. Nagasawa, M.; Mitsui, S.; En, S.; Ohtani, N.; Ohta, M.; Sakuma, Y.; Onaka, T.; Mogi, K.; Kikusui, T. Social evolution. Oxytocin-gaze positive loop and the coevolution of human-dog bonds. Science 2015, 348, 333-336. [CrossRef]

232. Li, Q.; Becker, B.; Wernicke, J.; Chen, Y.; Zhang, Y.; Li, R.; Le, J.; Kou, J.; Zhao, W.; Kendrick, K.M. Foot massage evokes oxytocin release and activation of orbitofrontal cortex and superior temporal sulcus. Psychoneuroendocrinology 2019, 101, 193-203. [CrossRef] [PubMed]

233. Morhenn, V.; Beavin, L.E.; Zak, P.J. Massage increases oxytocin and reduces adrenocorticotropin hormone in humans. Altern. Ther. Health Med. 2012, 18, 11-18. [PubMed]

234. Portnova, G.V.; Proskurnina, E.V.; Sokolova, S.V.; Skorokhodov, I.V.; Varlamov, A.A. Perceived pleasantness of gentle touch in healthy individuals is related to salivary oxytocin response and EEG markers of arousal. Exp. Brain Res. 2020, 238, 2257-2268. [CrossRef] [PubMed] 
235. Dukíc, H. Music, Brain Plasticity and the Resilience: The Pillars of New Receptive Therapy. Psychiatr. Danub. 2018, 30, 141-147. [PubMed] 236. Russo, S.J.; Murrough, J.W.; Han, M.H.; Charney, D.S.; Nestler, E.J. Neurobiology of resilience. Nat. Neurosci. 2012, 15, 1475-1484. [CrossRef]

237. Ungar, M. Resilience after maltreatment: The importance of social services as facilitators of positive adaptation. Child Abus. Negl. 2013, 37, 110-115. [CrossRef] 